University of Nebraska - Lincoln

DigitalCommons@University of Nebraska - Lincoln

High-resolution stalagmite reconstructions of

Australian-Indonesian monsoon rainfall variability during Heinrich stadial 3 and Greenland interstadial 4

\author{
Sophie C. Lewis \\ The Australian National University \\ Michael K. Gagan \\ The Australian National University \\ Linda Ayliffe \\ The Australian National University \\ Jian-xin Zhao \\ The University of Queensland \\ Wahyoe S. Hantoro \\ Indonesian Institute of Sciences \\ See next page for additional authors \\ Follow this and additional works at: https://digitalcommons.unl.edu/nasapub \\ Part of the Physical Sciences and Mathematics Commons
}

Lewis, Sophie C.; Gagan, Michael K.; Ayliffe, Linda; Zhao, Jian-xin; Hantoro, Wahyoe S.; Treble, Pauline; Hellstrom, John C.; LeGrande, Allegra N.; Kelley, Maxwell; Schmidt, Gavin A.; and Suwargadi, Bambang W., "High-resolution stalagmite reconstructions of Australian-Indonesian monsoon rainfall variability during Heinrich stadial 3 and Greenland interstadial 4" (2011). NASA Publications. 66.

https://digitalcommons.unl.edu/nasapub/66

This Article is brought to you for free and open access by the National Aeronautics and Space Administration at DigitalCommons@University of Nebraska - Lincoln. It has been accepted for inclusion in NASA Publications by an authorized administrator of DigitalCommons@University of Nebraska - Lincoln. 


\section{Authors}

Sophie C. Lewis, Michael K. Gagan, Linda Ayliffe, Jian-xin Zhao, Wahyoe S. Hantoro, Pauline Treble, John C. Hellstrom, Allegra N. LeGrande, Maxwell Kelley, Gavin A. Schmidt, and Bambang W. Suwargadi 


\title{
High-resolution stalagmite reconstructions of Australian-Indonesian monsoon rainfall variability during Heinrich stadial 3 and Greenland interstadial 4
}

\author{
Sophie C. Lewis ${ }^{\mathrm{a}, *}$, Michael K. Gagan ${ }^{\mathrm{a}}$, Linda K. Ayliffe ${ }^{\mathrm{a}}$, Jian-xin Zhao ${ }^{\mathrm{b}}$, Wahyoe S. Hantoro ${ }^{\mathrm{c}}$, \\ Pauline C. Treble ${ }^{\mathrm{a}, \mathrm{d}}$, John C. Hellstrom ${ }^{\mathrm{e}}$, Allegra N. LeGrande ${ }^{\mathrm{f}}$, Maxwell Kelley ${ }^{\mathrm{f}}$, \\ Gavin A. Schmidt ${ }^{f}$, Bambang W. Suwargadi c \\ ${ }^{a}$ Research School of Earth Sciences, The Australian National University, Canberra, ACT, 0200, Australia \\ ${ }^{\mathrm{b}}$ Centre for Microscopy and Microanalysis, The University of Queensland, Brisbane, QLD, 4072, Australia \\ ${ }^{\mathrm{c}}$ Research and Development Center for Geotechnology, Indonesian Institute of Sciences, Bandung 40135, Indonesia \\ d Australian Nuclear Science and Technology Organisation, Lucas Heights, NSW, 2234, Australia \\ e School of Earth Sciences, The University of Melbourne, Parkville, VIC, 3010, Australia \\ f NASA Goddard Institute for Space Studies and Center for Climate Systems Research, Columbia University, 2880 Broadway, New York, NY, 10025, USA
}

\section{A R T I C L E I N F O}

\section{Article history:}

Received 18 June 2010

Received in revised form 22 December 2010

Accepted 23 December 2010

Available online 26 January 2011

Editor: P. DeMenocal

\section{Keywords:}

speleothem

isotopes

trace elements

Heinrich stadial 3

monsoon

Intertropical convergence zone (ITCZ)

\begin{abstract}
A B S T R A C T
Little is known about the possible teleconnections between abrupt climatic changes originating in the North Atlantic and precipitation dynamics in the Australian-Indonesian summer monsoon (AISM) domain. We examine the climatic impacts of Heinrich stadial 3 (HS3) and Greenland interstadials 4 and 3 (GIS4/3) on AISM-associated precipitation through a high-resolution analysis of stable isotope $\left(\delta^{18} \mathrm{O}, \delta^{13} \mathrm{C}\right)$ and trace element $(\mathrm{Mg} / \mathrm{Ca}, \mathrm{P} / \mathrm{Ca})$ ratios in a stalagmite from Liang Luar cave, Flores, Indonesia. Sixteen high precision ${ }^{230}$ Th dates indicate that stalagmite LR07-E1 grew rapidly $(\sim 0.3-1.0 \mathrm{~mm} / \mathrm{yr})$ in two phases between $\sim 31.5-$ 30.1 ka and $\sim 27.8-25.6$ ka, separated by a $\sim 2.3$ kyr unconformity. Temporally consistent abrupt responses occur in the Flores record during HS3 and GIS4, which are coherent with changes in stalagmite $\delta^{18} \mathrm{O}$ records from China and Brazil. The response of low-latitude precipitation to HS3 cooling and GIS4 warming, as demonstrated by the widely separated sites, comprises three distinct simplified phases: (1) a strong southward migration of the ITCZ during HS3 is associated with a decrease in rainfall at Liang Luar cave and in China, while wetter conditions are reconstructed from Brazil, (2) represents the peak of HS3 impacts and an extended hiatus begins in the Flores record and (3) where suggested dry conditions at Liang Luar throughout GIS4 form part of a coherent north-south anti-phasing in precipitation changes. The reconstructed changes are also broadly consistent with NASA GISS ModelE-R simulations of a Heinrich-like freshwater perturbation in the North Atlantic basin, which produces a southward shift in the ITCZ. The relationship between the palaeoclimate records indicates that atmospheric teleconnections rapidly propagate and synchronise climate change across the hemispheres during periods of abrupt climate change. Our findings augment recent proposals that large-scale atmospheric re-organisations during stadials and interstadials play a key role in driving changes in atmospheric $\mathrm{CO}_{2}$ concentration, air temperature and global climate change.
\end{abstract}

(c) 2011 Elsevier B.V. All rights reserved.

\section{Introduction}

The last glacial period was punctuated by a series of rapid warming and cooling events, most prominently around the North Atlantic basin, where repeated millennial-scale temperature variations (DansgaardOeschger interstadials and Heinrich stadials) occurred with magnitudes similar to a full glacial-interglacial cycle (Dansgaard et al., 1993; Heinrich, 1988). Recent studies of oxygen isotopic variability $\left(\delta^{18} \mathrm{O}, \delta\right.$ in permil units, \%, of the subscripted value relative to a known standard) in speleothems (calcium carbonate cave deposits) have

\footnotetext{
* Corresponding author. Tel.: +61 26125 4303; fax: +61 261250738. E-mail address: sophie.lewis@anu.edu.au (S.C. Lewis).
}

revealed the impact of these abrupt climate changes in the tropical hydrological cycle through atmospheric teleconnections to the monsoon domains of tropical South America and East Asia. Speleothem $\delta^{18} \mathrm{O}$ records collectively indicate a broad north-south precipitation anti-phasing across the hemispheres during shortlived, cool Heinrich stadials, under a southward displacement of the intertropical convergence zone (ITCZ), with significant impacts on monsoon-associated rainfall (Wang et al., 2006). High-resolution analyses of $\delta^{18} \mathrm{O}$ in a Chinese stalagmite over Heinrich stadial 1 (HS1) show an abrupt shift in the character of the East Asian monsoon (EAM), with a rapid onset of $<2 \mathrm{yr}$ and a duration of $\sim 500 \mathrm{yr}$ (Treble et al., 2007).

The expression of Heinrich stadials in the Southern Hemisphere tropical regions remains unclear. Palaeoclimatic reconstructions from 
the southern African monsoon region, for example, indicate variability in the impact of Heinrich stadials and their ability to propagate into the southern tropics (Tierney et al., 2008). At Lake Tanganyika, a variety of responses are reported through successive $H$ stadials, with isotopic excursions coeval with HS1 and HS4 interpreted as periods of regional aridity, while HS2 and HS3 are not discernible (Tierney et al., 2008). Currently, little is known about the impact of abrupt North Atlantic-driven climatic changes on the southern sector of the Australian-Indonesian summer monsoon (AISM), largely because existing palaeo-records are limited by their chronological and sampling resolutions. Characterising the occurrence, timing, duration and magnitude of abrupt shifts in precipitation within the AISM system is particularly important for understanding the role of the tropics in transporting heat and moisture to higher latitudes.

During Heinrich stadials, $\delta^{18} \mathrm{O}$ increases in Chinese speleothems are commonly interpreted as showing a weakening of the East Asian monsoon (Wang et al., 2001; Wang et al., 2008; Zhao et al., 2010), while $\delta^{18} \mathrm{O}$ decreases in Brazilian stalagmites are linked to an intensification of the monsoon in tropical and subtropical South America (Cruz et al., 2006; Cruz et al., 2009; Wang et al., 2004). Stalagmite $\delta^{18} \mathrm{O}$ is widely used as a proxy for palaeorainfall through the 'amount effect', whereby isotopic ratios of precipitation $\left(\delta^{18} \mathrm{O}_{p}\right)$ are inversely correlated to local rainfall amount (Dansgaard, 1964). The isotopic composition of precipitation is, however, influenced by multiple site-specific factors, which further complicate climatic interpretations. For example, $\delta^{18} \mathrm{O}_{p}$ integrates total changes in atmospheric circulation from source to the site of rainout, including changes in regional hydrology, the initial evaporative source region, the degree of rain-out during transit and atmospheric mixing, together with fluctuations in local rainfall amount (Dansgaard, 1964; Rozanski et al., 1993). As a result, the interpretation of speleothem $\delta^{18} \mathrm{O}$ from monsoon areas based on the amount effect alone may not be valid at all sites (LeGrande and Schmidt, 2009; Schmidt et al., 2007). Furthermore, there is ambiguity in the interpretations of speleothem $\delta^{18} \mathrm{O}$ in terms of monsoon variability, which is variously used to describe the seasonality of precipitation or the amount of summertime precipitation, again complicating isotopic interpretations (Dayem et al., 2010; Lewis et al., 2010). In this study, references to changes in the intensity of the AISM refer to a dynamical definition of monsoon changes (Lewis et al., 2010; Webster and Yang, 1992) using zonal wind shear as an indicator of regional convective activity and latent heat released during the monsoon season as precipitation.

We present a high-resolution analysis of $\delta^{18} \mathrm{O}, \delta^{13} \mathrm{C}$ and trace elements $(\mathrm{Mg} / \mathrm{Ca}$ and $\mathrm{P} / \mathrm{Ca})$ from a near-annually banded stalagmite (LR07-E1) from Flores, southern Indonesia. We use high-resolution stalagmite $\delta^{18} \mathrm{O}$ changes to reconstruct abrupt shifts in precipitation within the AISM around the time of Heinrich stadial 3 (HS3, 30 ka) and Greenland interstadials 4 and 3 (GIS4/GIS3, 29-28 ka) and compare this record to contemporaneous speleothems from eastern China (Zhao et al., 2010) and Brazil (Wang et al., 2006). Recent studies have shown that $\mathrm{Mg} / \mathrm{Ca}$ and $\mathrm{P} / \mathrm{Ca}$ are sensitive to changes in precipitation amount and related soil productivity (e.g. Fairchild et al., 2001; Treble et al., 2003). We use laser-ablation ICP-MS techniques to analyse $\mathrm{Mg} / \mathrm{Ca}$ and $\mathrm{P} / \mathrm{Ca}$ ratios at ultra-high-resolution (sub-seasonal) as a means of refining the uranium-series chronology and supporting high-resolution $\delta^{18} \mathrm{O}$ interpretations. Finally, we integrate LR07-E1 $\delta^{18} \mathrm{O}$ records with model simulations of Heinrich-like ('hosing') simulations using the isotope-enabled NASA GISS ModelE-R general circulation model (Hansen et al., 2007; Schmidt et al., 2006) to constrain the dominant controls on regional $\delta^{18} \mathrm{O}$ variability and validate climatic interpretations made from speleothem $\delta^{18} \mathrm{O}$.

\section{Study area and climatology}

Liang Luar cave $\left(8^{\circ} 32^{\prime} \mathrm{S}, 120^{\circ} 26^{\prime} \mathrm{E}, 550\right.$ m.a.s.l.) is part of an extensive cave system on Flores, Indonesia (Fig. 1). The narrow cave

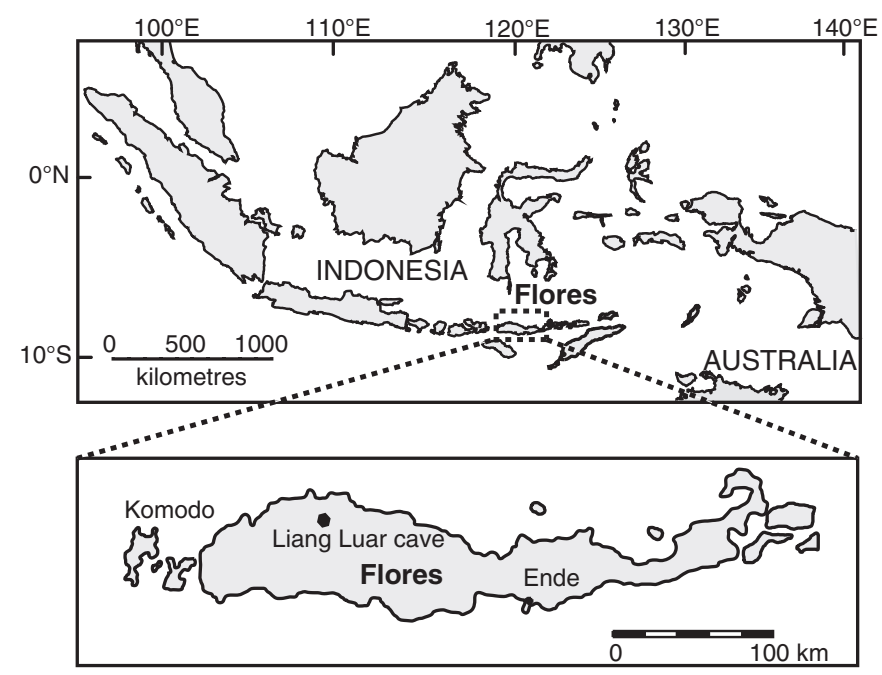

Fig. 1. Location of Liang Luar cave $\left(8^{\circ} 32^{\prime} \mathrm{S}, 120^{\circ} 26^{\prime} \mathrm{E}\right)$, southern Indonesia. The island of Flores lies near the southern limit of the intertropical convergence zone during the austral summer.

entrance $(\sim 2 \mathrm{~m} \times 4 \mathrm{~m})$ and long passages (up to $\sim 1.7 \mathrm{~km}$ ) of Liang Luar restrict airflow and maintain stability in the cave environment. Cave humidity was determined to be close to $100 \%$ during the dry season and internal temperatures $\sim 25^{\circ} \mathrm{C}$, which is close to the mean annual surface air temperature. CMAP (Climate Prediction Centre Merged Analysis of Precipitation, Xie and Arkin, 1996) observations indicate average annual rainfall in the region is $\sim 1800 \mathrm{~mm} / \mathrm{yr}$, with $\sim 70 \%$ of rainfall occurring during the summer monsoon months of December to March.

Annual precipitation over southern Indonesia is largely controlled by the AISM and associated seasonal latitudinal displacements of the ITCZ. During the Southern Hemisphere summer, warm Australasian continental and oceanic temperatures, coupled with cold land surface temperatures over Asia, draw surface airflow from Asia towards Australia. The region undergoes a distinct wind flow reversal, from a low-level southeasterly trade wind flow in winter (May to September), to a northwesterly flow in summer (December to March), due to the southward displacement of the ITCZ. Modelled seasonal and annual average precipitation sources to southern Indonesia are relatively local, with distinct seasonal source region changes (Fig. 2). The modelled wet season source is comparatively local $(\sim 340 \mathrm{~km}$ mean vapour transport

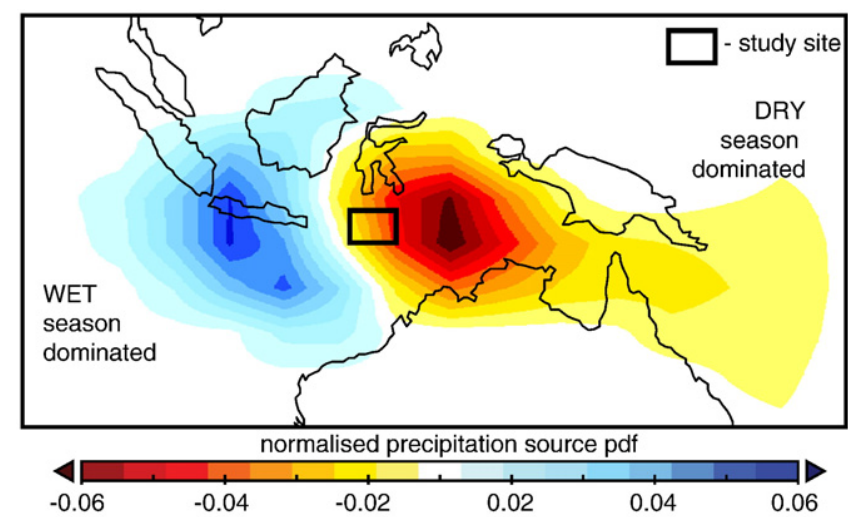

Fig. 2. NASA GISS ModelE simulation of seasonal precipitation source anomalies (wetdry season) for Flores. Simulations utilise the atmospheric general circulation ModelE equipped with vapour source distribution (VSD) tracers resolved to wave number 11 (effective horizontal resolution $\sim 8^{\circ} \times 10^{\circ}$ ) (Kelley, 2003; Lewis et al., 2010). VSDs are unitless probability density functions (pdfs), normalised by the maximum probability density. All pre-industrial boundary conditions and atmospheric compositions are appropriate to circa 1880 . 
distance) relative to the dry season source, which has a mean locus east of Flores ( $9^{\circ} 33^{\prime} \mathrm{S}, 123^{\circ} 55^{\prime} \mathrm{E}, \sim 400 \mathrm{~km}$ mean vapour transport distance). Furthermore, the dry season source is relatively diffuse compared with the wet season, with part of the source extending eastward of the mean location. The observed long-term mean $\delta^{18} \mathrm{O}_{p}$ values in the region are 5.3-5.4\% VSWOM (Aggarwal et al., 2004) and analysis of $\delta^{18} \mathrm{O}$ in rainwater collected near Liang Luar cave over the period of August 2006 to May 2007 showed a marked difference of $\sim 6.8 \%$. VSMOW (Vienna Standard Mean Ocean Water) in $\delta^{18} \mathrm{O}_{p}$ between the mean wet season $(-10.3 \%$ ) and tradewind-associated $(-3.5 \%$ ) rainfall (Griffiths et al., 2009).

\section{Sample description and methodology}

Stalagmite LR07-E1 (Fig. 3) is 1.73 m long and composed of finegrained white to brown opaque calcite with semi-regular millimetrescale laminae. Sample LR06-C3 is $\sim 0.3 \mathrm{~m}$ long, with two prominent hiatuses at $80 \mathrm{~mm}$ and $160 \mathrm{~mm}$ from the top of the specimen. The age of the section below the older hiatus, comprised of laminated yellow/ brown translucent calcite, overlaps with portions of the E1 stalagmite. Stalagmites C3 and E1 were recovered $\sim 900 \mathrm{~m}$ and $\sim 1200 \mathrm{~m}$ from the cave entrance, respectively. Samples were slabbed longitudinally along their growth axes and their surfaces polished to reveal growth bands for uranium-series dating, stable isotope and trace element analysis.

\section{1. ${ }^{230}$ Th dating}

The chronology for E1 was determined from a subset of 18 high precision Th/U dates (sample positions indicated in Fig. 3). Fourteen samples were analysed on a Fisons VG Sector 54-30 thermal ionisation mass spectrometer (TIMS) at the University of Queensland (UQ) and four paired samples on a Finnigan Neptune multi-collector inductively coupled plasma mass spectrometer (MC-ICP-MS) at The Australian National University (ANU) for cross-laboratory verification. The TIMS and MC-ICP-MS ages agree within measurement error and require minimal corrections for detrital ${ }^{230} \mathrm{Th}$. Two age measurements were made by TIMS for sample C3 at UQ. Age determinations were made on $\sim 0.5 \mathrm{~g}$ of powdered material, which was milled for stable isotope analysis (E1) or cut from the specimen using a dental grinding wheel (C3). Uranium-series techniques were applied following the methods of McCulloch and Mortimer (2008) and Zhao, et al. (2001).

\subsection{Stable isotopes}

Samples for $\delta^{18} \mathrm{O}$ and $\delta^{13} \mathrm{C}$ analysis from stalagmites E1 and $\mathrm{C} 3$ were milled in a continuous channel along the central growth axis (Supplementary Table S1). Given the physical constraints of milling large samples, uneven increments approximating $\sim 10 \mathrm{~mm}$ were sampled. Additionally, an E1 sub-section (E1-D) was micro-milled continuously at $\sim 0.1 \mathrm{~mm}$ increments for ultra-high-resolution analysis of $\delta^{18} \mathrm{O}$ and $\delta^{13} \mathrm{C}$ immediately prior to a growth unconformity marked by a distinct colour change from white to brown calcite (Fig. 3, Supplementary Table S1). This sub-section is $\sim 35 \mathrm{~mm}$ in length and characterised by a low-porosity finely laminated calcite. As LR07-E1 is exceptionally fast growing and sub-seasonal resolution reconstructions can be achieved using conventional sampling techniques, only approximately every second milled sample within E1-D was analysed for $\delta^{18} \mathrm{O}$ and $\delta^{13} \mathrm{C}$. For E1, a total of $385 \delta^{18} \mathrm{O}$ and $\delta^{13} \mathrm{C}$ analyses were conducted (174 at $\sim 10 \mathrm{~mm}$ and 211 at $\sim 0.1 \mathrm{~mm}$ resolution). For C3, stalagmite stable isotopes were determined from 13 samples at $\sim 10 \mathrm{~mm}$ resolution.

Stable isotope $\left(\delta^{18} \mathrm{O}\right.$ and $\delta^{13} \mathrm{C}$ ) values were measured from calcite samples weighing $180-200 \mu \mathrm{g}$ using a Finnigan MAT-251 mass spectrometer coupled with an automated individual carbonate reaction (Kiel) device at the ANU. Carbon dioxide was extracted for isotope analysis by reacting the calcite powders with $105 \% \mathrm{H}_{3} \mathrm{PO}_{4}$ at $90{ }^{\circ} \mathrm{C}$. Stable isotope ratios for calcite are reported as per mil deviations relative to the Vienna Peedee belemnite (VPDB) standard. The analytical precision $(2 \sigma)$ for 115 NBS-19 in-run measurements was $0.06 \%$ for $\delta^{18} \mathrm{O}$ and $0.04 \%$ or for $\delta^{13} \mathrm{C}$.

\subsection{Trace elements}

Measurements of $\mathrm{Mg} / \mathrm{Ca}$ and $\mathrm{P} / \mathrm{Ca}$ ratios were made using the Varian laser ablation inductively coupled plasma mass spectrometer (LA-ICP-MS) at The Australian National University. Trace element ratios were measured for an E1 sub-sample (E1-D, as used for the stable isotopes analysis) along the central growth axis, adjacent to the speleothem surface subsequently milled for high-resolution stable isotope analysis. The sample was mounted, cleaned using a preablation spot size of $47 \mu \mathrm{m}$ at $5 \mathrm{~Hz}$ and element compositions were measured using an ablation spot size of $28 \mu \mathrm{m}$ at $10 \mathrm{~Hz}$, relative to NIST612 standard (e.g. Desmarchelier et al., 2006; Sinclair et al., 1998). Trace element data were pre-processed (background subtraction, drift correction and spike filtering) and box smoothed to approximately the same order of magnitude as adjacent stable isotope data, in order to allow a comparison between the proxies to be made. The frequency characteristics of linearly detrended ratios were analysed using the Blackman-Tukey method (Blackman and Tukey, 1958) in MATLAB to determine the expression of any possible annual cycling. It should also be noted that element ratios measured here are semi-quantitative and are not employed for absolute palaeoenvironmental reconstructions as such, but rather used primarily to constrain the uranium-series chronology throughout the high-resolution sub-sample transect and to support highresolution stable isotope reconstructions.

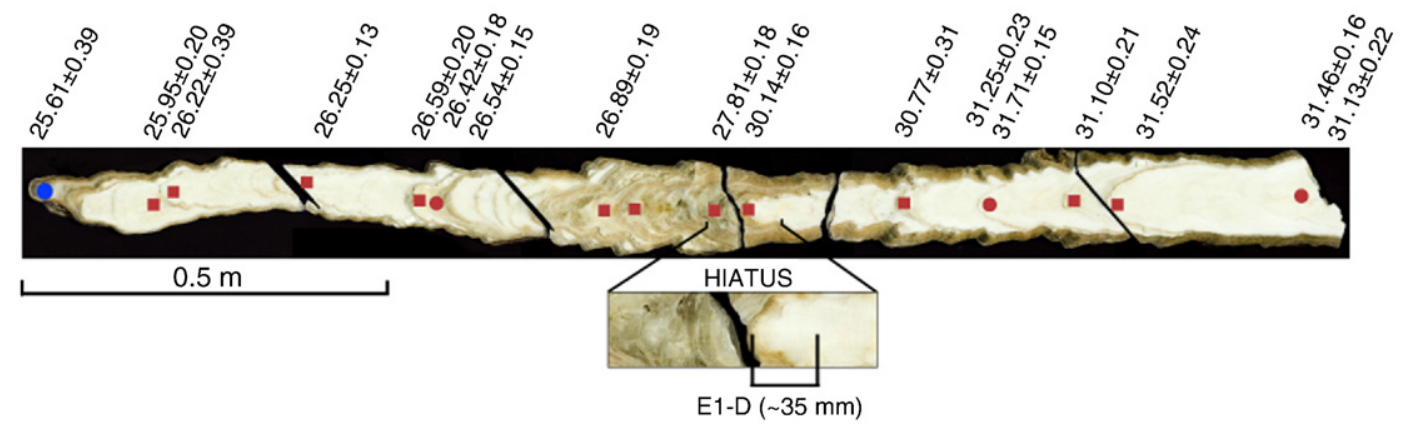

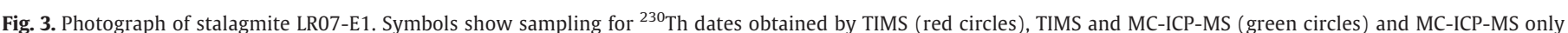

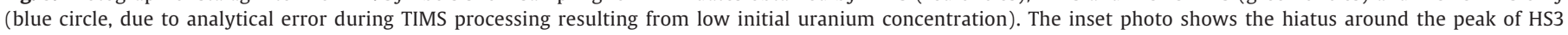

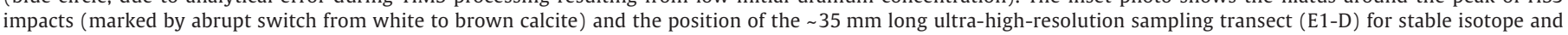
trace element analyses. 


\section{Results}

\subsection{Chronology}

The age range determined from the ${ }^{230} \mathrm{Th}$ measurements from E1 was $31.52 \pm 0.24$ to $25.61 \pm 0.39 \mathrm{ka}$ (Table 1 ). The age-depth model for E1 (Fig. 4A) was established from 16 measurements, using the stratigraphical constraint method outlined by Drysdale et al. (2005). This method employs a constrained Monte Carlo procedure under the assumption that any sequence of ages must exhibit a monotonic increase along the growth axis of a stalagmite. The ${ }^{230} \mathrm{Th} /{ }^{232} \mathrm{Th}$ ratios of samples are randomised and the distributions of those that yield monotonic age models are used to estimate the initial ${ }^{230} \mathrm{Th} /{ }^{232} \mathrm{Th}$ value of the detrital phase (Hellstrom, 2006). Two dates (LR07-E1-E-a16r/Fa1r) were excluded from the age-depth model on the basis that they are incompatible with several surrounding ages. Given that both U/Th analytical methods (McCulloch and Mortimer, 2008; Zhao, et al., 2001) produced incongruous ages, preservation issues in the lower section of E1 (below 1280 mm from the tip) are considered possible. There are no inversions elsewhere in the chronology. The age-depth model for C3 was determined using a linear interpolation between the two measured ages (25.91 \pm 0.16 and $27.92 \pm 0.17$, Table 1$)$.

Deposition of E1 occurred during two distinct periods of growth from $\sim 31.5$ to $30.1 \mathrm{ka}$ and $\sim 27.8$ to $25.6 \mathrm{ka}$, separated by a visible hiatus located $\sim 960 \mathrm{~mm}$ below the top of the stalagmite. The hiatus is visually associated with a distinct change from white to brown calcite and the average stalagmite growth rate is $\sim 0.4 \mathrm{~mm} / \mathrm{yr}$ above and $\sim 0.6 \mathrm{~mm} / \mathrm{yr}$ below the hiatus. Growth rates within these sections are variable with relatively slower average growth rates $(\sim 0.3 \mathrm{~mm} / \mathrm{yr})$, for example, immediately preceding the hiatus and faster growth rates $(\sim 1.0 \mathrm{~mm} / \mathrm{yr})$ within the finely laminated basal section (Fig. 4B). Growth rates for E1 are significantly faster than $\mathrm{C} 3(\sim 0.06 \mathrm{~mm} / \mathrm{yr}$, Fig. 5$)$ and the fastest encountered in speleothems from Liang Luar cave.

\subsection{Validation of stalagmite $\delta^{18} \mathrm{O}$ record}

Previous studies have shown that shifts in Liang Luar stalagmite $\delta^{18} \mathrm{O}$ during the Holocene largely correspond to changes in the $\delta^{18} \mathrm{O}$ of precipitation (Griffiths et al., 2009; Griffiths et al., 2010a,b), and model studies indicate that rainfall amount is the dominant control on $\delta^{18} \mathrm{O}_{p}$ during Heinrich-like events (Lewis et al., 2010). The use of stalagmite $\delta^{18} \mathrm{O}$ as a palaeorainfall proxy, however, requires evaluation of the veracity of the records. For example, if $\mathrm{CO}_{2}$ degassing during stalagmite growth is sufficiently rapid, Rayleigh fractionation causes systematic changes in calcite $\delta^{18} \mathrm{O}$ that have no direct relationship to the cave dripwater isotopic composition, nor to climate (Hendy, 1971).

Griffiths et al. (2009; 2010a) showed that contiguous Holocene stalagmite $\delta^{18} \mathrm{O}$ records from Liang Luar cave are in agreement, and that the most recent stalagmite calcite was deposited in isotopic equilibrium with cave dripwaters. In this study, where ancient stalagmite calcite $\delta^{18} \mathrm{O}$ cannot be compared directly with cave dripwater, we validate the $\delta^{18} \mathrm{O}$ record by demonstrating reproducibility of stalagmite $\delta^{18} \mathrm{O}$ records within Liang Luar cave. We employ the reproducibility test rather than the single growth layer Hendy (1971) tests, because their success or failure cannot readily be interpreted in terms of palaeoenvironmental signals determined from $\delta^{18} \mathrm{O}$ analysis along the central growth axis of a stalagmite (Dorale and Liu, 2009).

A rigorous test for isotopic equilibrium is the replication of contemporaneous stalagmite $\delta^{18} \mathrm{O}$ records from the same cave. Replication of profiles between two records occurs where kinetic processes are either absent or their net effect on speleothem calcite $\delta^{18} \mathrm{O}$ must have been the same. Consistent disequilibrium offsets are unlikely for spatially separated stalagmites as precipitating drips have a unique combination of flow path, $\mathrm{CO}_{2}$ partial pressure, residence time, concentration of solutes and degassing history. Our analysis of stalagmites LR07-E1 and LR06-C3, separated by 300 m within Liang Luar cave, and growing at vastly different rates, confirms that the $\delta^{18} \mathrm{O}$ records were deposited in isotopic equilibrium over the period $\sim 28$ $25.6 \mathrm{ka}$ ago (Fig. 5). Visually, variations in the stalagmite $\delta^{18} \mathrm{O}$ profiles are similar over this period and mean values agree within $\sim 0.1 \%$. On the basis of this replication test, we interpret the Liang Luar $\delta^{18} \mathrm{O}$ record in terms of changes in precipitation amount.

\section{3. $\delta^{18} O_{p}$ controls}

Previous model results demonstrate that over southern Indonesia during Heinrich-like events, $\delta^{18} \mathrm{O}_{p}$ changes are most closely associated with precipitation amount (Lewis et al., 2010). Further studies also

\section{Table 1}

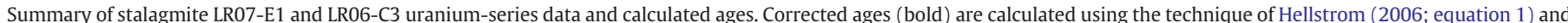

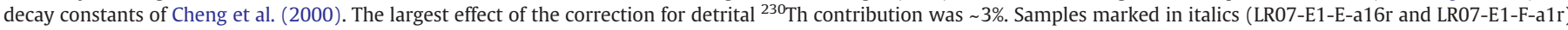

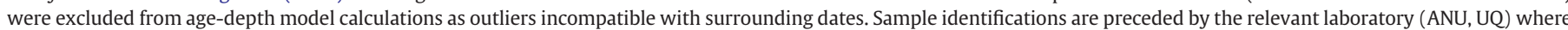
analyses were conducted.

\begin{tabular}{|c|c|c|c|c|c|c|c|c|c|}
\hline Sample ID & $\begin{array}{l}\text { Depth } \\
\text { (mm from tip) }\end{array}$ & $\begin{array}{l}\mathrm{U} \\
(\mathrm{ppm}) \pm 2 \sigma\end{array}$ & $\begin{array}{l}{ }^{232} \mathrm{Th} \\
(\mathrm{ppb}) \pm 2 \sigma\end{array}$ & ${ }^{230} \mathrm{Th} /{ }^{232} \mathrm{Th}$ & ${ }^{234} U /{ }^{238} U \pm 2 \sigma$ & ${ }^{230} \mathrm{Th} /{ }^{238} \mathrm{U} \pm 2 \sigma$ & $\begin{array}{l}\text { Age }(\mathrm{ka}) \\
\text { uncorrected } \pm 2 \sigma\end{array}$ & $\begin{array}{l}\text { Age }(\mathrm{ka}) \\
\text { corrected } \pm 2 \sigma\end{array}$ & $\begin{array}{l}\text { Corrected initial } \\
{ }^{234} \mathrm{U} /{ }^{238} \mathrm{U} \pm 2 \sigma\end{array}$ \\
\hline \multicolumn{10}{|l|}{ LR07-E1 } \\
\hline ANU-LR07-E1-A-e3r & 61 & $0.1469 \pm 0.0002$ & $3.041 \pm 0.001$ & 34 & $1.0793 \pm 0.0021$ & $0.2316 \pm 0.0013$ & $26.29 \pm 0.18$ & $25.61 \pm 0.39$ & $1.0852 \pm 0.0022$ \\
\hline UQ-LR07-E1-A-c1r & 194 & $0.2544 \pm 0.0003$ & $0.313 \pm 0.001$ & 569 & $1.0855 \pm 0.0025$ & $0.2306 \pm 0.0015$ & $25.99 \pm 0.20$ & $25.95 \pm 0.20$ & $1.0920 \pm 0.0027$ \\
\hline UQ-LR07-E1-A-b7r & 210 & $0.1553 \pm 0.0002$ & $0.100 \pm 0.001$ & 1083 & $1.0759 \pm 0.0031$ & $0.2304 \pm 0.0030$ & $26.24 \pm 0.40$ & $26.22 \pm 0.39$ & $1.0817 \pm 0.0033$ \\
\hline UQ-LR07-E1-B-b17r & 383 & $0.1410 \pm 0.0002$ & $0.101 \pm 0.003$ & 988 & $1.0825 \pm 0.0019$ & $0.2321 \pm 0.0009$ & $26.27 \pm 0.13$ & $26.25 \pm 0.13$ & $1.0889 \pm 0.0020$ \\
\hline UQ-LR07-E1-B-a13r & 566 & $0.2867 \pm 0.0004$ & $0.193 \pm 0.001$ & 1057 & $1.0794 \pm 0.0023$ & $0.2341 \pm 0.0015$ & $26.61 \pm 0.20$ & $26.59 \pm 0.20$ & $1.0856 \pm 0.0025$ \\
\hline UQ-LR07-E1-B-a10r & 595 & $0.2791 \pm 0.0003$ & $1.735 \pm 0.010$ & 115 & $1.0857 \pm 0.0017$ & $0.2356 \pm 0.0011$ & $26.62 \pm 0.15$ & $26.42 \pm 0.18$ & $1.0923 \pm 0.0019$ \\
\hline ANU-LR07-E1-B-a9r & 604 & $0.2430 \pm 0.0004$ & $0.054 \pm 0.000$ & 3211 & $1.0790 \pm 0.0016$ & $0.2335 \pm 0.0011$ & $26.55 \pm 0.15$ & $26.54 \pm 0.15$ & $1.0851 \pm 0.0017$ \\
\hline UQ-LR07-E1-C-b2r & 783 & $0.2727 \pm 0.0005$ & $0.858 \pm 0.003$ & 229 & $1.0785 \pm 0.0025$ & $0.2369 \pm 0.0013$ & $27.0 \pm 0.18$ & $26.89 \pm 0.19$ & $1.0847 \pm 0.0027$ \\
\hline UQ-LR07-E1-C-a9r & 871 & $0.3061 \pm 0.0007$ & $0.350 \pm 0.001$ & 642 & $1.0778 \pm 0.0036$ & $0.2419 \pm 0.0020$ & $27.67 \pm 0.28$ & $27.63 \pm 0.28$ & $1.0841 \pm 0.0039$ \\
\hline UQ-LR07-E1-C-a1r & 944 & $0.3540 \pm 0.0004$ & $1.355 \pm 0.010$ & 192 & $1.0723 \pm 0.0024$ & $0.2427 \pm 0.0012$ & $27.94 \pm 0.17$ & $27.81 \pm 0.18$ & $1.0782 \pm 0.0026$ \\
\hline UQ-LR07-E1-D-a11r & 960 & $0.2306 \pm 0.0002$ & $0.150 \pm 0.002$ & 346 & $1.0782 \pm 0.0017$ & $0.2614 \pm 0.0011$ & $30.21 \pm 0.16$ & $30.14 \pm 0.16$ & $1.0851 \pm 0.0018$ \\
\hline UQ-LR07-E1-E-b10r & 1162 & $0.2836 \pm 0.0003$ & $0.528 \pm 0.003$ & 6568 & $1.0807 \pm 0.0018$ & $0.2663 \pm 0.0023$ & $30.78 \pm 0.31$ & $30.77 \pm 0.31$ & $1.0881 \pm 0.0019$ \\
\hline UQ-LR07-E1-E-a17r & 1274 & $0.3136 \pm 0.0002$ & $1.409 \pm 0.010$ & 183 & $1.0789 \pm 0.0012$ & $0.2705 \pm 0.0016$ & $31.40 \pm 0.22$ & $31.25 \pm 0.23$ & $1.0862 \pm 0.0013$ \\
\hline$A N U-L R 07-E 1-E-a 16 r$ & 1283 & $0.2750 \pm 0.0005$ & $0.032 \pm 0.000$ & 7047 & $1.0772 \pm 0.0018$ & $0.2724 \pm 0.0010$ & $31.72 \pm 0.15$ & $31.71 \pm 0.15$ & $1.0844 \pm 0.0019$ \\
\hline UQ-LR07-E1-E-a4r & 1401 & $0.3590 \pm 0.0005$ & $0.088 \pm 0.001$ & 3329 & $1.0778 \pm 0.0025$ & $0.2100 \pm 0.0014$ & $31.11 \pm 0.21$ & $31.10 \pm 0.21$ & $1.0849 \pm 0.0027$ \\
\hline UQ-LR07-E1-F-a28r & 1461 & $0.2982 \pm 0.0003$ & $0.078 \pm 0.001$ & 3131 & $1.0779 \pm 0.0018$ & $0.2712 \pm 0.0017$ & $31.53 \pm 0.24$ & $31.52 \pm 0.24$ & $1.0852 \pm 0.0020$ \\
\hline ANU-LR07-E1-F-a2r & 1723 & $0.3764 \pm 0.0007$ & $0.063 \pm 0.000$ & 4917 & $1.0841 \pm 0.0012$ & $0.2723 \pm 0.0012$ & $31.46 \pm 0.16$ & $31.46 \pm 0.16$ & $1.0919 \pm 0.0012$ \\
\hline UQ-LR07-E1-F-a1r & 1728 & $0.4934 \pm 0.0006$ & $0.089 \pm 0.001$ & 4538 & $1.0793 \pm 0.0026$ & $0.2686 \pm 0.0015$ & $31.13 \pm 0.13$ & $31.13 \pm 0.22$ & $1.0866 \pm 0.0028$ \\
\hline \multicolumn{10}{|l|}{ LR06-C3 } \\
\hline UQ-LR06-C3-4 & 161 & $0.1759 \pm 0.0002$ & $0.051 \pm 0.001$ & 2809 & $1.2660 \pm 0.0024$ & $0.2700 \pm 0.0011$ & $25.97 \pm 0.16$ & $25.91 \pm 0.16$ & $1.3622 \pm 0.0024$ \\
\hline UQ-LR06-C3-1 & 284 & $0.2330 \pm 0.0002$ & $0.021 \pm 0.000$ & 9548 & $1.2664 \pm 0.0016$ & $0.2882 \pm 0.0013$ & $27.94 \pm 0.17$ & $27.92 \pm 0.17$ & $1.3704 \pm 0.0017$ \\
\hline
\end{tabular}



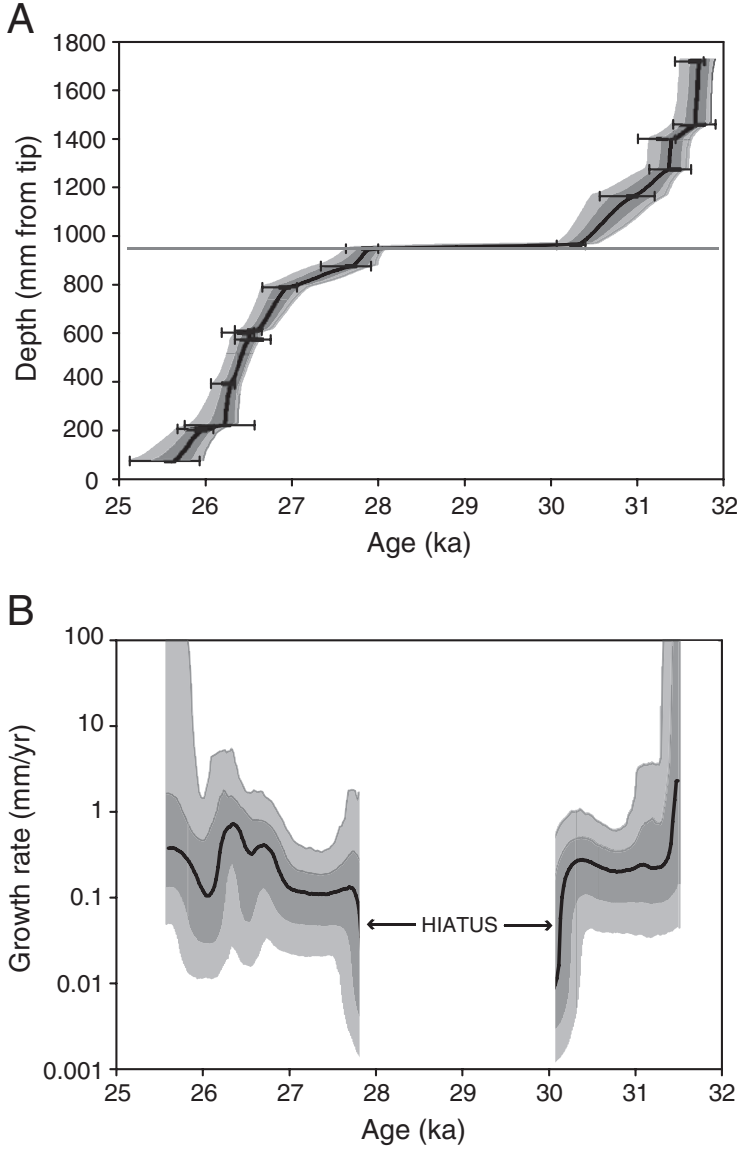

Fig. 4. (A) Age-depth profile for stalagmite LR07-E1, determined using a stratigraphical constraint Monte Carlo technique (Drysdale et al., 2005; Hellstrom, 2006). The ${ }^{230} \mathrm{Th}$ ages are indicated $( \pm 2 \sigma)$, together with $1 \sigma$ (light shading) and $2 \sigma$ (dark shading) age model uncertainty envelopes. Corrected ages are shown in grey with raw ages in black. The horizontal line indicates the location of the unconformity. (B) Growth rate versus age for stalagmite LR07-E1, with $1 \sigma$ and $2 \sigma$ uncertainty envelopes indicated. The hiatus occurring around peak HS3 conditions, following the first stalagmite growth phase is also marked.

suggest that in coastal settings in the western tropical Pacific, $\delta^{18} \mathrm{O}_{p}$ is correlated to local rainfall amount during other types of climatic change such as El Niño-Southern Oscillation variability (Tindall et al., 2009). Changes in the amount of precipitation are considered most

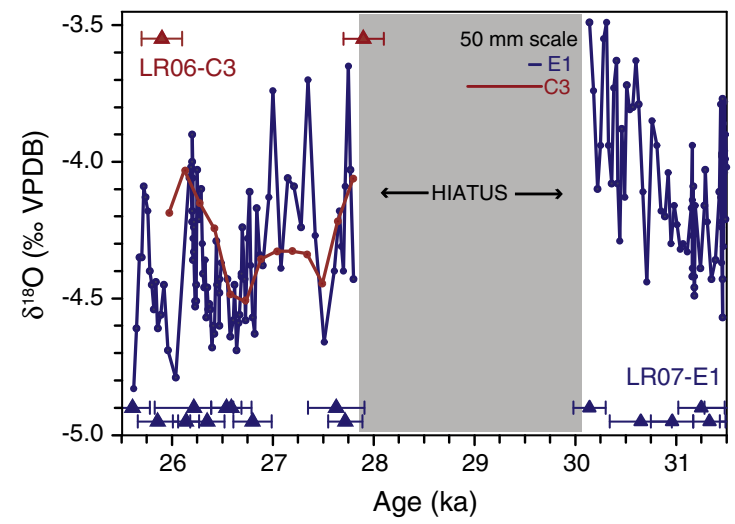

Fig. 5. Stalagmite LR07-E1 (blue) and LR06-C3 (red) $\delta^{18} \mathrm{O}$ time series. Uranium-series age error bars are colour-coded for each stalagmite. The scale bar demonstrates the varying growth rates between the stalagmites (E1 $\sim 0.5 \mathrm{~mm} / \mathrm{yr} ; \mathrm{C} 3 \sim 0.06 \mathrm{~mm} / \mathrm{yr}$ ), indicating the approximate length of time for each sample to grow $50 \mathrm{~mm}$. relevant for $\delta^{18} \mathrm{O}$ interpretations at coastal sites directly influenced by the ITCZ (Rozanski et al., 1993). Flores is situated on a strong spatial gradient in the $\delta^{18} \mathrm{O}$ of mean annual rainfall near the southern limit of the modern summer ITCZ (Aggarwal et al., 2004). As such, this site is likely highly sensitive to variability in latitudinal ITCZ migrations and associated rainfall fluctuations. Observational studies of modern rainfall over Flores (Griffiths et al., 2010a) also support model analyses indicating that $\delta^{18} \mathrm{O}_{p}$ correlates well with rainfall amount.

Overall, we suggest that $\delta^{18} \mathrm{O}_{p}$ over Indonesia records changes in the precipitation amount, largely caused by shifts in the mean position of the ITCZ and the intensity of associated convection. It should be noted that the $\delta^{18} \mathrm{O}_{p}$ integrates multiple drivers of variability and as such, the interpretation of $\delta^{18} \mathrm{O}$ variability reconstructed from palaeoclimatic archives is often complex. Source region changes due to shifts in the ITCZ and land-sea distributions, for example, likely provide a secondary impact on $\delta^{18} \mathrm{O}_{p}$ on longer timescales. Furthermore, isotope-climate relationships may be different over different timescales and types of climatic change (LeGrande and Schmidt, 2009; Schmidt et al., 2007).

\subsection{Stalagmite $\delta^{18} \mathrm{O}$ record and trace element profiles}

Stalagmite LR07-E1 $\delta^{18} \mathrm{O}$ values at $\sim 20$-year resolution fluctuate throughout the record, ranging from $-3.5 \%$ o to $-4.8 \%$, with an average $\delta^{18} \mathrm{O}$ value of $-4.3 \%$ (Fig. 5). Generally, the $\delta^{18} \mathrm{O}$ values increase irregularly from $\sim 31.5 \mathrm{ka}$ to a maximum at $\sim 30.1 \mathrm{ka}$ and then decrease from $\sim 27.8$ to $25.6 \mathrm{ka}$. The termination of the first growth phase $(\sim 31.5-30.1 \mathrm{ka})$ is marked by a $\delta^{18} \mathrm{O}$ maximum immediately preceding the hiatus. A slowing of growth rates and narrowing of the width of stalagmite LR07-E1 over this interval suggest that the drip rate slowed in the period leading to the unconformity. Hiatuses in stalagmite deposition are commonly due to a slowing of dripwater supply and have been used to reconstruct dry conditions during climatic excursions elsewhere (Cai et al., 2008; Cruz et al., 2009). To test the possibility that monsoon-associated rainfall decreased before stalagmite LR07-E1 stopped growing, we performed an ultra-highresolution (seasonal-scale) $\delta^{18} \mathrm{O}$ analysis of the final century of stalagmite growth. The $\delta^{18} \mathrm{O}$ profile shows a substantial ${ }^{18} \mathrm{O}$ enrichment towards the unconformity (Fig. 6), which, if interpreted in terms of rainfall amount, indicates that a drying trend led to the cessation of stalagmite growth.

Our interpretation of the LR07-E1-D $\delta^{18} \mathrm{O}$ record can be crosschecked by examining trace element variability at ultra-highresolution over the same growth interval. $\mathrm{Mg} / \mathrm{Ca}$ and $\mathrm{P} / \mathrm{Ca}$ in speleothem calcite, in particular, provide a multi-proxy means for understanding past hydrological variations (e.g. Desmarchelier et al., 2006; Johnson et al., 2006; Treble et al., 2003). Mg/Ca variations in Liang Luar stalagmites have been shown to reflect changes in meteoric infiltration rates, which are influenced by hydrological changes at the surface (Griffiths et al., 2010a). High speleothem $\mathrm{Mg} / \mathrm{Ca}$ ratios have been used extensively as an indicator of palaeo-aridity (Fairchild and Treble, 2009) and also speleothem P/Ca may provide a proxy for soil profile temperature and moisture (Treble et al., 2003).

Spectral analysis of the $\mathrm{Mg} / \mathrm{Ca}$ and $\mathrm{P} / \mathrm{Ca}$ profiles indicates a significant spectral peak at $\sim 0.4 \mathrm{~mm} /$ cycle. Trace element variations on near-annual scales in stalagmites have previously been used to construct relative chronologies (Desmarchelier et al., 2006; Treble et al., 2003). The $0.4 \mathrm{~mm} /$ cycle suggests that, for the length of E1-D, 90 near-annual growth increments were analysed, in agreement with the time interval $(\sim 100 \mathrm{yr})$ indicated by the ${ }^{230} \mathrm{Th}$ chronology (Fig. 4B). The trends toward higher $\mathrm{Mg} / \mathrm{Ca}$ and lower $\mathrm{P} / \mathrm{Ca}$ values in LR07-E1-D are well correlated $(R=-0.75)$ and indicate drier conditions in the $\sim 60$ near-annual increments prior to the hiatus (Fig. 6). Taken together, the coherent shifts in stalagmite E1-D growth rate, $\delta^{18} \mathrm{O}$, and trace element profiles suggest that a $\sim 60 \mathrm{yr}$ drying trend occurred prior to the cessation of calcite precipitation. 

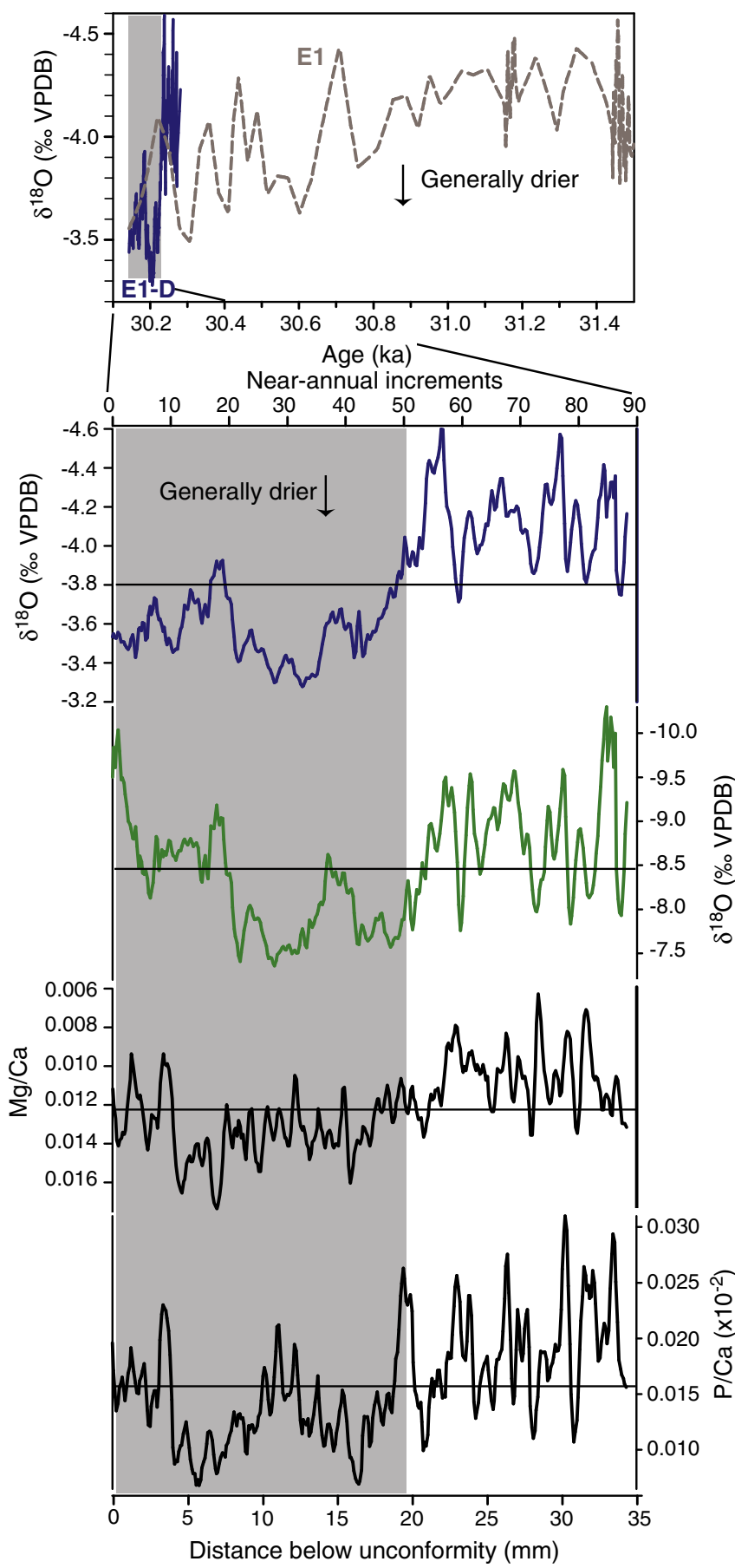

Fig. 6. Comparison of high-resolution $\delta^{18} \mathrm{O}$ (blue), $\delta^{13} \mathrm{C}$ (green) and LA-ICP-MS trace element $(\mathrm{Mg} / \mathrm{Ca}, \mathrm{P} / \mathrm{Ca})$ profiles along section E1-D in stalagmite LR07-E1. The position of the E1-D $\delta^{18} \mathrm{O}$ profile (solid curve) is shown on the $\sim 1.4 \mathrm{kyr} \delta^{18} \mathrm{O}$ record for LR07-E1 (dashed blue curve) prior to the hiatus leading into GIS4. Consistent spectral characteristics determined from the composite trace element ratios indicate that section E1-D spans $\sim 90 \mathrm{yr}$ of speleothem growth prior to the hiatus. Horizontal lines indicate average values for each profile over these $\sim 90 \mathrm{yr}$ and grey shading highlights a shift to drier conditions beginning $50-60 \mathrm{yr}$ prior to the cessation of stalagmite growth.

\section{Discussion}

\subsection{Temporal and spatial evolution of HS3 and GIS4}

The timing of HS3 impacts in the North Atlantic is placed at $~ 31 \mathrm{ka}$ and may be correct to within $1000 \mathrm{yr}$ (Hemming, 2004). In the EAM region, Zhao et al. (2010) correlate a $\delta^{18} \mathrm{O}$ increase in stalagmite records from two Chinese caves at $\sim 30.1$ ka with HS3 and interpret this as a weak monsoon event. At Botuverá cave in Brazil, a decrease in $\delta^{18} \mathrm{O}$ during the HS3 interval is centred on $~ 30 \mathrm{ka}$ and considered to be a wet period associated with intensification of the South American monsoon (Wang et al., 2006).

The spatial and temporal response of monsoon-associated rainfall in China (Zhao et al., 2010), Flores, and Brazil (Wang et al., 2006) can be summarised as three simplified main phases of hydrological change occurring over the period 30.8-28.0 ka (covering HS3-GIS4, Fig. 7). Phase 1 ( 30.8 to $30.2 \mathrm{ka}$ ) is characterised by rapid antiphased changes in the stalagmite $\delta^{18} \mathrm{O}$ records from China and Brazil, associated with changes in the intensity of the monsoon and an average southward shift in the ITCZ. In China, Zhao et al. (2010) interpret a large $\delta^{18} \mathrm{O}$ increase as a significant decrease in summer monsoon rainfall corresponding to HS3 cooling in the North Atlantic. In contrast, Wang et al. (2006) interpret the $\delta^{18} \mathrm{O}$ decrease recorded in Brazil at this time as an inter-hemispheric anti-phased intensification of the South American summer monsoon rainfall. At Liang Luar cave, a $\sim 0.5 \%$ increase in speleothem $\delta^{18} \mathrm{O}$ (a drying trend) occurs during phase 1. Furthermore, a progressive reduction in the diameter of stalagmite LR07-E1 supports a decrease in drip rate and precipitation amount at this time in LR07-E1.

Collectively, phase 1 describes a substantial southward shift in the ITCZ in response to HS3 cooling, such that the mean position of the ITCZ is located at higher latitudes beyond Flores, resulting in a regional drying of the low southern latitudes around Flores. The HS3driven southward ITCZ displacement may have been large enough to produce disparate responses in the two Southern Hemisphere monsoon domains separated by $\sim 20^{\circ}$ of latitude. Additionally, the distinction should be made between tropical precipitation systems over the oceans (i.e. the ITCZ) and those influencing continental environments (i.e. the monsoons), as these are influenced by different forcings and are dynamically and often geographically distinct (Vuille and Werner, 2005). Shifts in the ITCZ, for example, are primarily driven by meridional thermal gradients, while the monsoons respond to a complex set of forcings that includes summer insolation, land-sea temperature contrasts, soil and vegetation feedbacks and extratropical cold air incursions. Hence, although southward oceanic ITCZ shifts during cold excursions are comparatively well constrained, over land such latitudinal migrations are not necessarily clear and may depend on feedbacks in the bio- and lithospheres. Furthermore, responses may be meridionally and zonally asymmetric and monsoon intensification may result without a concomitant ITCZ change (Cruz et al., 2009). As such, discrepant reconstructed hydrological responses between Flores and Brazil are unsurprising given the unique influences on the ITCZ in each location.

Phase 2 ( 30.2 to $29.6 \mathrm{ka}$ ) represents the peak of HS3 impacts on monsoon precipitation in Brazil (wetter) and China (drier) (Wang et al., 2006; Zhao et al., 2010). The dominant phase 2 feature in the Flores stalagmite record is the cessation of growth following abrupt geochemical $\left(\delta^{18} \mathrm{O}, \delta^{13} \mathrm{C}, \mathrm{Mg} / \mathrm{Ca}, \mathrm{P} / \mathrm{Ca}\right)$ changes that indicate a decrease in precipitation (Fig. 6). The growth hiatus in the Flores record suggests that the average position of the ITCZ is located southward of Flores during HS3.

Phase 3 ( 29.6 to $28.0 \mathrm{ka}$ ) defines the response of rainfall within the monsoon domains to HS3 recovery and the abrupt warming occurring over Greenland during GIS4 (Dansgaard et al., 1993). During this period, there was likely a rapid northward shift of the ITCZ in response to the changing thermal gradient across the hemispheres, and monsoon intensification occurs over China (Zhao et al., 2010). This is broadly similar, although of opposite sign, to hydrological changes reconstructed from Botuverá cave, Brazil, where a decrease in precipitation is recorded (Wang et al., 2006). The hiatus in stalagmite LR07-E1 is bracketed by uranium-series ages at $\sim 30.14 \pm 0.16 \mathrm{ka}$ and $\sim 27.81 \pm 0.18 \mathrm{ka}$ (Table 1 ), thus the expression of GIS4 within the 


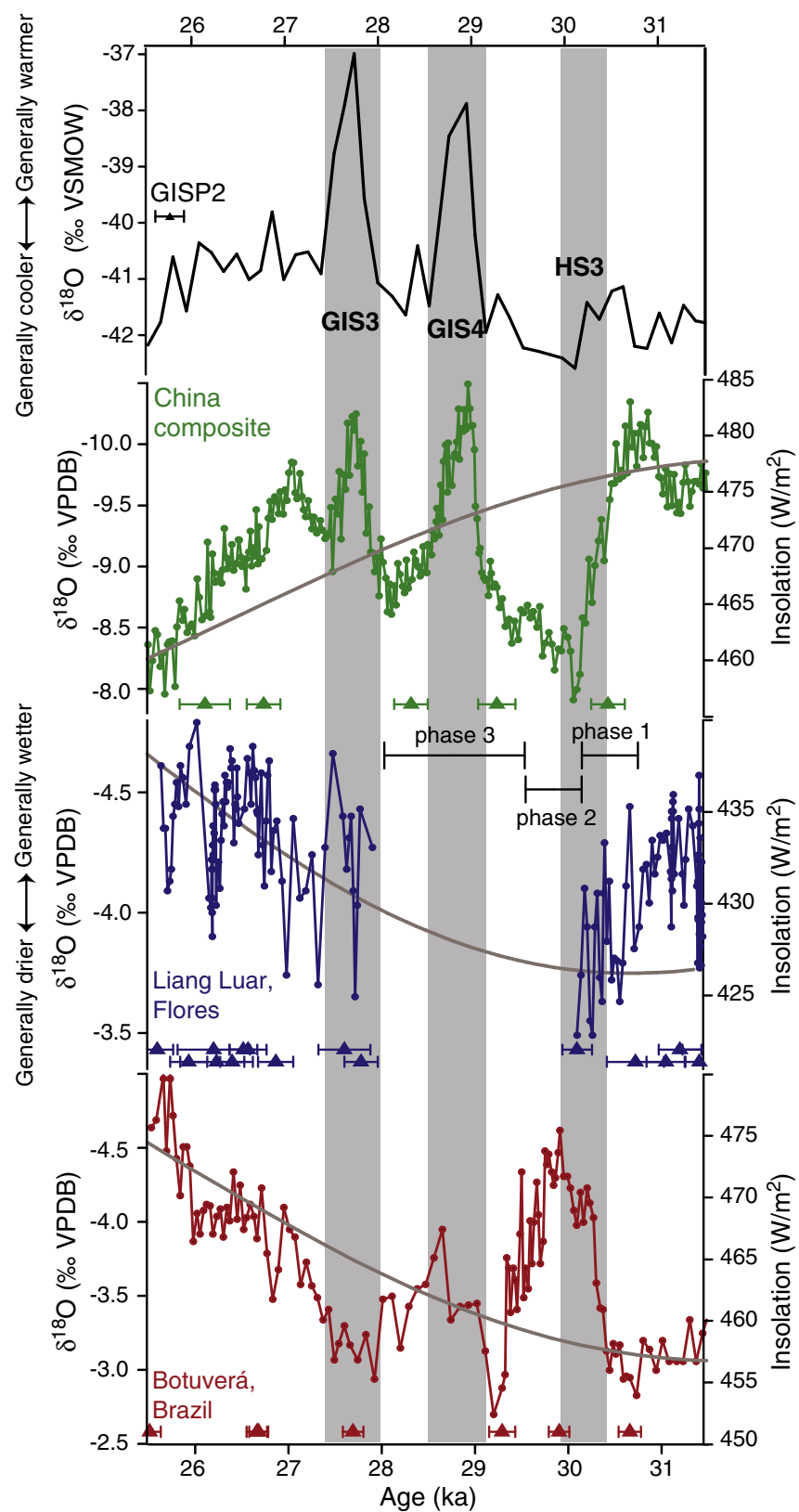

Fig. 7. Comparison of stalagmite $\delta^{18} \mathrm{O}$ records for Wulu and Sanbao caves, China (Zhao et al., 2010), in green, Liang Luar cave, Flores (LR07-E1), in blue and Botuverá cave, Brazil (BTV4C; Wang et al., 2006), in red, and the GISP2 ice core $\delta^{18} \mathrm{O}$ record (Grootes and Stuiver, 1997) in black. Grey shading indicates the timing of the Greenland interstadials 4 and 3 (GIS4, GIS3) and Heinrich stadial 3 (HS3) and proposed phases 1-3 are indicated. All ${ }^{230} \mathrm{Th}$ ages and errors are shown for stalagmite records and a minimum average age uncertainty is given for GISP2 ( $300 \mathrm{yr}$; Bender et al., 1999).

distinct stalagmite E1 unconformity (spanning 2.3 kyr) likely indicates a significant dry phase in response to the northward shift of the ITCZ. During phase 3, the widely separated stalagmite records from Brazil, Flores and China show a spatially coherent north-south hydrological anti-phasing across the hemispheres.

Following phase 3, LR07-E1 stalagmite growth in Flores resumes and the isotopic trends in all three records largely follow local summer insolation forcing. In Flores, $\delta^{18} \mathrm{O}$ values centre around $-4.3 \%$, which is similar to the average LR07-E1 $\delta^{18} \mathrm{O}$ value recorded between 31.5 and $30.8 \mathrm{ka}$, prior to the onset of HS3 drying in Flores. A similar recovery from GIS4 drying is also recorded at Botuverá cave at this time, with a progressive decrease in $\delta^{18} \mathrm{O}$ beginning $\sim 28 \mathrm{ka}$, corresponding to increasing local summer insolation. The trends toward lower $\delta^{18} \mathrm{O}$ (increased precipitation) at Liang Luar and Botuverá caves begin during the period of increased monsoon activity in China that is coincident with GIS3 in Greenland (Zhao et al., 2010). In China, GIS3 is registered as a smaller excursion than GIS4, and is followed by a progressive $\delta^{18} \mathrm{O}$ increase as local summer insolation decreases. The muted response of the Southern Hemisphere stalagmite $\delta^{18} \mathrm{O}$ records during GIS3, compared with China, indicates complexity in the spatial response of the low latitudes to climatic excursions originating in the high northern latitudes, and possibly relates to subtle shifts in the locus of the ITCZ.

Dynamical perspectives on the observed temporal and spatial complexity of Greenland interstadial expressions are limited as the basic forcing mechanisms are not well constrained. Consequently, model experiments do not provide much insight into DansgaardOeschger events (Kageyama et al., 2010). Dansgaard-Oeschger events have also been described as wind (rather than oceanic circulation) driven phenomena and are consequently characterised by rapid, widespread teleconnection but are also comparatively unstable (Wunsch, 2006). As such, remote expressions of interstadials, if any perturbation occurs, are likely diverse between regions. Finally, the termination of stalagmite LR07-E1 growth at 25.6 ka occurred as the top of the stalagmite grew close to the cave ceiling and likely blocked drip formation, and hence cessation of growth at this time is not attributed to a climatic cause.

In summary, the speleothem $\delta^{18} \mathrm{O}$ records from China, Flores and Brazil reveal coherent spatial and temporal simplified patterns in the low-latitude impact of climatic events HS3 and GIS4/GIS3 originating in the high northern latitudes. During HS3, under a strong southward shift in the ITCZ and with significant changes in regional monsoon intensity, drier conditions are recorded at Liang Luar cave and in China, and wetter conditions are recorded in Brazil. In the low latitudes, GIS4 is characterised by a coherent inter-hemispheric antiphasing of precipitation, likely in response to a rapid northward shift in the ITCZ, suggesting a temporally robust, though complex, relationship between hydrological changes across the hemispheres.

\subsection{Data-model comparison of HS3}

Model results provide a useful context for interpreting proxy records and in order to put the low-latitude hydrological records into a broader context, we simulate a Heinrich-like event using the GISS ModelE-R (Lewis et al., 2010). In this 'hosing' simulation, following the Paleoclimate Modelling Intercomparison Project (PMIP) protocol, freshwater is added uniformly over the North Atlantic $\left(50^{\circ}\right.$ to $\left.70^{\circ} \mathrm{N}\right)$ at a rate of $1 \mathrm{~Sv}\left(1 \mathrm{~Sv}=10^{6} \mathrm{~m}^{3} / \mathrm{s}\right)$ over 100 model years. A control simulation, with no freshwater perturbation, was run in parallel with all boundary conditions and atmospheric composition appropriate to the pre-industrial period (circa 1880). The results are presented as hosing anomalies $(\Delta)$ relative to mean control values (Fig. 8). Hosing experiments are highly idealised and not necessarily representative of a particular climatic event, although are useful in examining the response of tropical precipitation to abrupt cooling in the North Atlantic.

Following freshwater injection the simulated perturbation of the sea surface temperature gradient across the hemispheres results in a southward shift in the ITCZ by $1-2$ model gridboxes $\left(\sim 4-8^{\circ}\right.$ in latitude). Throughout China, hosing-driven anomalies are spatially complex (Fig. 8). Overall increases in precipitation (ANN $0.2 \mathrm{~mm} /$ day; JJA $0.1 \mathrm{~mm} /$ day; DJF $0.9 \mathrm{~mm} /$ day) are modelled, together with enrichment in ${ }^{18} \mathrm{O}$ (ANN $\Delta \delta^{18} \mathrm{O}_{p} 0.6 \%$; JJA $\Delta \delta^{18} \mathrm{O}_{p} 0.6 \%$; DJF $\Delta \delta^{18} \mathrm{O}_{p}$ $0.2 \%$ ). Following hosing, year-round increases in precipitation are modelled, associated with intensification in the AISM. Flores also lies near the simulated contour of zero change, particularly during the wet season months. Through gridboxes encompassing Liang Luar there is a hosing-driven annual average increase in precipitation of $\sim 0.8 \mathrm{~mm} /$ 

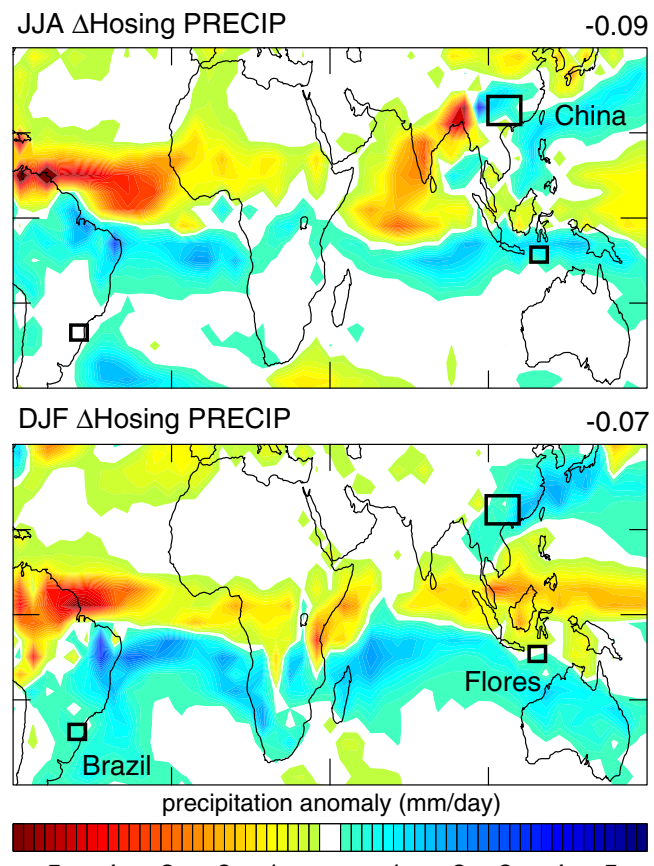

$\begin{array}{lllll}-5 & -4 & -3 & -2 & -1\end{array}$
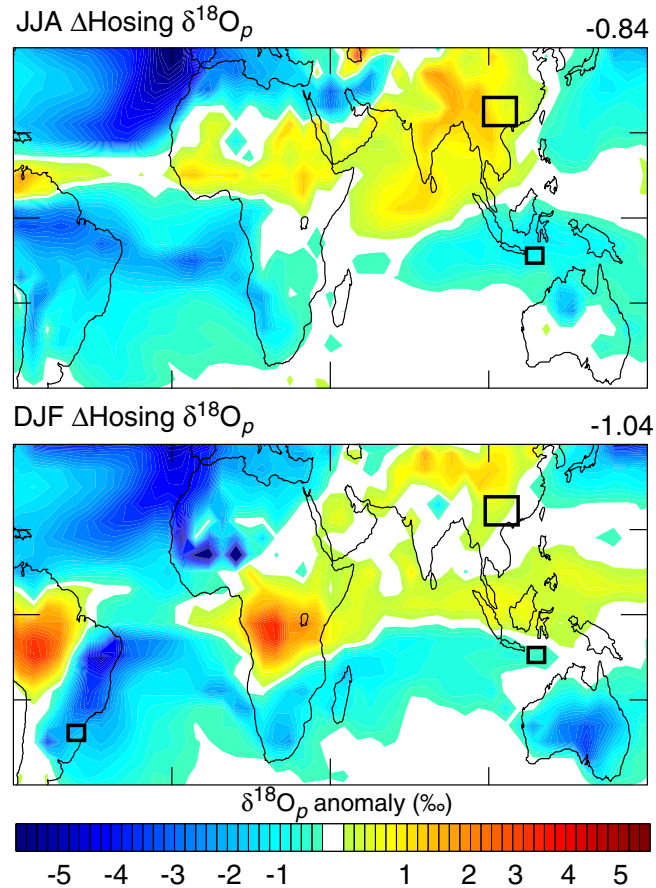

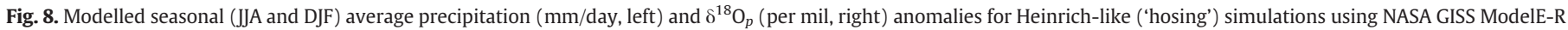

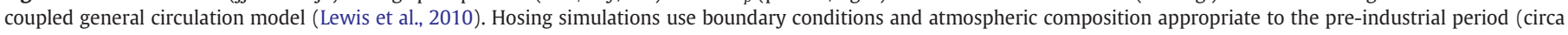

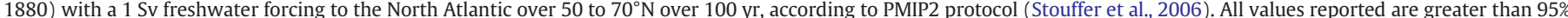

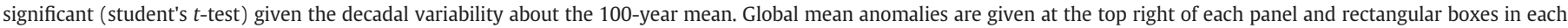
panel indicate gridboxes encompassing cave sites in Flores, China (Zhao et al., 2010) and Brazil (Wang et al., 2006).

day (relative to modern at $95 \%$ significance level about the decadal mean) and an average annual $\delta^{18} \mathrm{O}$ decrease of $\sim 0.7 \%$. Seasonally, the largest simulated precipitation anomalies occur during the winter season ( $\sim 0.8 \mathrm{~mm} /$ day) with austral summer increases $(\sim 0.6 \mathrm{~mm} /$ day). Over Brazil, seasonally pronounced increases in precipitation (ANN $1.1 \mathrm{~mm} /$ day; JJA $0.7 \mathrm{~mm} /$ day; DJF $1.3 \mathrm{~mm} /$ day) and $\delta^{18} \mathrm{O}_{p}$ decreases (ANN $\Delta \delta^{18} \mathrm{O}_{p}-2.7 \%$; JJA $\Delta \delta^{18} \mathrm{O}_{p}-1.7 \%$; DJF $\Delta \delta^{18} \mathrm{O}_{p}$ $-3.1 \%$ ) are simulated.

Over regions encompassing the cave sites in China and Brazil, modelled hosing-driven $\delta^{18} \mathrm{O}_{p}$ anomalies are broadly consistent with average reconstructed $\delta^{18} \mathrm{O}$ changes from multiple speleothems (Lewis et al., 2010). Within the AISM-dominated subtropics, geochemical changes in lake sediments from Lynch's Crater, northeastern Australia, suggest that Heinrich stadials 1 to 3 are expressed as wet intervals (Muller et al., 2008). Broadly, there is a coherence of hydrological responses in spatially disparate southern subtropical regions (northern Australia and Brazil) during HS3, in agreement with modelled precipitation increases.

The expression of HS3 in southern Indonesia as a dry period provides a coherent climatic response with average Heinrich stadial changes reconstructed northwards in Borneo (Partin et al., 2007) and over the East Asian monsoon region (Wang et al., 2001; Zhao et al., 2010) and a discordant response with changes in the southern subtropics (Muller et al., 2008; Wang et al., 2006). There are currently no further high-resolution, high-quality records covering Heinrich stadials from within the region for comparison, although the Younger Dryas stadial ( $\sim 2.6$ to $11.5 \mathrm{ka}$ ) is evident as a prominent decrease in ${ }^{18} \mathrm{O}$ values (increase in precipitation) at Liang Luar cave (Griffiths et al., 2010b). The Younger Dryas, while not directly analogous to Heinrich excursions, provides a useful comparison to both modelled hosing-driven $\delta^{18} \mathrm{O}_{p}$ anomalies and reconstructed $\delta^{18} \mathrm{O}$ changes covering Heinrich intervals. Over Flores, the Younger Dryas is interpreted as an increase in summer monsoon related precipitation over Flores (Griffiths et al., 2010b), which is in agreement with modelled hydrological anomalies.
Precipitation over southern Indonesia is particularly sensitive to latitudinal migrations in the ITCZ, and hence the temporal complexity of responses in southern Indonesia to abrupt North Atlantic cooling (HS3 and YD) likely relates to the different magnitudes in the events originating in the North Atlantic and to their variable ability to propagate into the Southern Hemisphere tropics through ITCZ perturbations. More broadly within the southern tropics, temporally variable responses to Heinrich stadials are reported in the southern tropics of Africa, from Lake Tanganyika, where HS4 and HS1 are evident as abrupt isotopic enrichments, and HS3 and HS2 are, conversely, not discernible (Tierney et al., 2008). Model results also demonstrate the spatial complexity of hydrological changes in the southern Indonesian region, with Flores situated near the simulated contour of zero $\delta^{18} \mathrm{O}_{p}$ and precipitation changes.

Overall, model simulations are an idealised Heinrich-like experiment that is not boundary condition specific and may not resolve the complex and subtle precipitation changes occurring over climatically sensitive regions. Simulations do not take into account, for example, marine isotope stage 3 changes in ice volume and continentality and hence do not capture the full range of ITCZ perturbations. Model studies that have employed a North Atlantic freshwater forcing on a LGM base climate state, for example, reveal that ITCZ shifts outside the tropical Atlantic Ocean are not robust and highly model dependent (Kageyama et al., 2010; Singarayer and Valdes, 2010). Furthermore, tropical precipitation responses are highly sensitive to prescribed boundary conditions and forcings, which are unique for each Heinrich stadial. Overall, ensemble GCM results indicate that strong ITCZ migrations are dynamically possible under climatic conditions characterised by a collapsed Atlantic Meridional Overturning Circulation, and that these can result in dry perturbations around Indonesia.

Identifying the nature of the climatic connections between the hemispheres is important for understanding abrupt climatic events. Recent studies link disrupted global patterns of oceanic and atmospheric circulation during stadials with significant changes in biogeochemical cycles, atmospheric $\mathrm{CO}_{2}$ concentrations, and global 
temperature (Denton et al., 2010). During Northern Hemisphere stadials, when the ITCZ is pushed southward by cool northern sea surface conditions, a poleward shift also occurs in the Southern Hemisphere westerly wind belt, producing pulses of ocean upwelling, associated increases in atmospheric $\mathrm{CO}_{2}$ and warming over the Southern Ocean and Antarctica (e.g. Anderson et al. 2009). The southward migration of the ITCZ during HS3 may play a key role in driving $\mathrm{CO}_{2}$ from the Southern Ocean, causing regional warming over Antarctica and ultimately leading to reinvigoration of the thermohaline circulation and subsequent warming over Greenland during GIS4. The weak monsoon event linked to HS3 in China is the longest Asian monsoon stadial occurring between $\sim 32.5$ and $20.6 \mathrm{ka}$ (Zhao et al., 2010) and is correlated to the largest Antarctic warming event in this interval (EPICA Community Members, 2006). The comparatively strong displacement of the ITCZ during HS3, indicated by the Liang Luar cave stalagmite record, supports the proposal that a north-south coupling of the hemispheres may be a fundamental driver of global climate change.

\section{Conclusions}

Stalagmite LR07-E1 from Liang Luar cave, Indonesia, provides a high-resolution, independently dated multi-proxy record of AISM rainfall variability during the HS3 cold and GIS4/3 warm intervals in the North Atlantic region. The record spans the period from $~ 31.5$ to $30.1 \mathrm{ka}$ and $\sim 27.8-25.6 \mathrm{ka}$ in two calcite growth phases separated by a hiatus. Throughout the stalagmite record, AISM-associated precipitation anomalies occur in response to thermally driven perturbations in the mean location of the ITCZ that originate in the North Atlantic, and a temporally consistent relationship between hydrological changes in the AISM and EAM throughout the E1 record is demonstrated. During HS3 (phase 1), under a southward shift in the ITCZ driven by cool sea surface conditions in the North Atlantic, a decrease in rainfall is recorded at Liang Luar cave and in China, while wetter conditions are reconstructed in South America. An extended hiatus within stalagmite E1 begins during phase 2, which is the peak of low-latitude HS3 impacts, and suggests the mean location of the ITCZ is southward of Flores. Throughout GIS4 (phase 3), dry conditions at Liang Luar comprise a coherent pattern of inter-hemispheric anti-phasing of hydrological responses with Brazil and China.

Stalagmite records demonstrate that southern Indonesian precipitation is sensitive to latitudinal ITCZ migrations and temporally complex responses to abrupt Northern Hemisphere cooling occur over this region. For example, the AISM-associated rainfall anomaly during HS3 was likely of opposite sign to that during the YD event. This discordance is due to the different magnitudes in the events originating in the North Atlantic and to their varying abilities to propagate into the Southern Hemisphere through ITCZ shifts. The strong shift in the ITCZ during HS3, evidenced by the disparate precipitation responses between the southern tropics and subtropics, is associated with a significant weak monsoon event in China and a large warm period in Antarctica. Furthermore, the large southward HS3-driven ITCZ shift may be linked to large-scale oceanic and atmospheric changes that led to the reinvigoration of the thermohaline circulation and the resultant warming over Greenland characterising GIS4 (Denton et al., 2010).

The novel integration of multi-proxy geochemical analyses (including stable isotope and trace element data sets), together with general circulation model simulations, provides a comprehensive analysis of large-scale low-latitude hydrological responses to abrupt climatic change. Overall, the results demonstrate the utility of integrating multi-proxy reconstructions with isotope-enabled model simulations to improve site-specific interpretations. Additional speleothem records from this climatically sensitive region will further constrain the range of climatic changes in the AISM, associated with latitudinal ITCZ shifts occurring during abrupt climatic excursions originating in the North Atlantic. Further understanding of the diverse remote responses to Greenland interstadials similarly requires an increase in the spatial and temporal coverage of tropical hydrological reconstructions. Future work integrating model results may benefit from employing regional downscaling techniques and studies involving site-specific forward modelling describing calcite precipitation may also improve the utility of multi-disciplinary approaches.

Supplementary materials related to this article can be found online at doi:10.1016/j.epsl.2010.12.048.

\section{Acknowledgements}

We thank H. Scott-Gagan, J. Cali, J. Cowley, S. Eggins and L. Kinsley for help with isotope and trace element analyses; D. Qu, Y. Feng, G. Mortimer and M. McCulloch for assistance with the uranium-series chronology; and N. Anderson, G. Smith, J. Rutledge, R. Drysdale, M. Griffiths, E. St. Pierre, E. Yulianto and the Indonesian Institute of Sciences (LIPI) for logistical help and assistance with fieldwork, carried out under LIPI Research Permit number 2748/SU.3/KS/2007. This study was funded by APA/ASS/JAE Scholarships and Paterson Fellowship/ANU Vice-Chancellor travel grants to S.C.L and Australian Research Council Discovery grant DP0663274 to M.K.G., J.-X. Z. and W. S.H. NSF ATM 07-53868 supports A.N.L and travel for S.C.L. We thank RSES and NASA GISS for institutional support. We gratefully acknowledge the comments of P. deMenocal and three anonymous reviewers, which greatly improved this manuscript.

\section{References}

Aggarwal, P.K., Fröhlich, K., Kulkarni, K.M., Gourcy, L.L., 2004. Stable isotope evidence for moisture sources in the Asian summer monsoon under present and past climate regimes. Geophys. Res. Lett. 31, L08203, doi:10.1029/2004GL019911.

Anderson, R.F., Ali, S., Bradtmiller, L.I., Nielsen, S.H.H., Fleisher, M.Q., Anderson, B.E., Burckle, L.H., 2009. Wind-Driven Upwelling in the Southern Ocean and the Deglacial Rise in Atmospheric CO2. Science 323, 1443-1448, doi:10.1126/ science. 1167441.

Bender, M.L., Malize, J., Orchardo, J., Sowers, T., Jouzel, J., 1999. High precision correlations of Greenland and Antarctic ice core records over the last $100 \mathrm{kyr}$. In: Clark, P.U., Webb, R.S., Keigwin, L.D. (Eds.), Mechanisms of global climate change at millennial time scales. AGU, Washington DC, pp. 149-164.

Blackman, R.B., Tukey, J.W., 1958. The Measurement of Power Spectra. Dover Publications, New York.

Cai, B., Edwards, R.L., Cheng, H., Tan, M., Wang, X., Liu, T., 2008. A dry episode during the Younger Dryas and centennial-scale weak monsoon events during the early Holocene: a high-resolution stalagmite record from southeast of the Loess Plateau. China Geophys. Res. Lett. 35, doi:10.1029/2007GL030986.

Cheng, H., Edwards, R.L., Hoff, J., Gallup, C.D., Richards, D.A., Asmerom, Y., 2000. The half-lives of uranium-234 and thorium-230. Chem. Geol. 169, 17-33, doi:10.1016/ S0009-2541(99)00157-6.

Cruz, F.W.J., Burns, S.J., Karmann, I., Sharp, W.D., Vuille, M., Ferrari, J.A., 2006. A stalagmite record of changes in atmospheric circulation and soil processes in the Brazilian subtropics during the Late Pleistocene. Quatern. Sci. Rev. 25, 2749-2761, doi:10.1016/j.quascirev.2006.02.019.

Cruz, F.W., Vuille, M., Burns, S.J., Wang, X., Cheng, H., Werner, M., Edwards, L.R., Karmann, I., Auler, A.S., Nguyen, H., 2009. Orbitally driven east-west antiphasing of South American precipitation. Nat. Geosci. 2, 210-214, doi:10.1038/ngeo444.

Dansgaard, W., 1964. Stable isotopes in precipitation. Tellus 16, 436-468.

Dansgaard, W., Johnsen, S.J., Clausen, H.B., Dahl-Jensen, D., Gundestrup, N.S., Hammer, C.U., Hvidberg, C.S., Steffensen, J.P., Sveinbjornsdottir, A.E., Jouzel, J., Bond, G., 1993. Evidence for general instability of past climate from a 250-kyr ice-core record. Nature 364, 218-220.

Dayem, K.E., Molnar, P., Battisti, D.S., Roe, G.H., 2010. Lessons learned from oxygen isotopes in modern precipitation applied to interpretation of speleothem records of paleoclimate from eastern Asia. Earth Planet. Sci. Lett. 295, 219-230, doi:10.1016/j. epsl.2010.04.003.

Denton, G.H., Anderson, R.F., Toggweiler, J.R., Edwards, R.L., Schaefer, J.M., Putnam, A.E., 2010. The last glacial termination. Science 328, 1652-1656, doi:10.1126/ science. 1184119 .

Desmarchelier, J.M., Hellstrom, J.C., McCulloch, M.T., 2006. Rapid trace element analysis of speleothems by ELA-ICP-MS. Chem. Geol. 231, 102-117, doi:10.1016/j. chemgeo.2006.01.002.

Dorale, J.A. Liu, Z., 2009. Limitations of Hendy test criteria in judging the paleoclimatic suitability of speleothems and the need for replication. J. Cave Karst Stud. 71, 73-80.

Drysdale, R.N., Zanchetta, G., Hellstrom, J.C., Fallick, A.E., Zhao, J.-X., 2005. Stalagmite evidence for the onset of the Last Interglacial in southern Europe at $129 \pm 1 \mathrm{ka}$. Geophys. Res. Lett. 32, L24708, doi:10.1029/2005gl024658. 
EPICA Community Members, 2006. One-to-one coupling of glacial climate variability in Greenland and Antarctica. Nature 444, 195-198, doi:10.1038/nature05301.

Fairchild, I.J., Treble, P.C., 2009. Trace elements in speleothems as recorders of environmental change. Quatern. Sci. Rev. 28, 449-468, doi:10.1016/j.quascirev.2008.11.007.

Fairchild, I.J., Baker, A., Borsato, A., Frisia, S., Hinton, R.W., McDermott, F., Tooth, A.F., 2001. Annual to sub-annual resolution of multiple trace-element trends in speleothems. J. Geol. Soc. Lond. 158, 831-841.

Griffiths, M.L., Drysdale, R.N., Gagan, M.K., Zhao, J.X., Ayliffe, L.K., Hellstrom, J.C., Hantoro, W.S., Frisia, S., Feng,, Y.X., Cartwright, I., Pierre, E.S., Fischer, M.J., Suwargadi, B.W., 2009. Increasing Australian-Indonesian monsoon rainfall linked to early Holocene sea-level rise. Nat. Geosci. 2, 636-639, doi:10.1038/ngeo605.

Griffiths, M.L., Drysdale, R.N., Gagan, M.K., Frisia, S., Zhao, J.-X., Ayliffe, L.K., Hantoro, W.S., Hellstrom, J.C., Fischer, M.J., Feng, Y.--x., Suwargadi, B.W., 2010a. Evidence for Holocene changes in Australian-Indonesian monsoon rainfall from stalagmite trace element and stable isotope ratios. Earth Planet. Sci. Lett. 292, 27-38, doi:10.1016/j. epsl.2010.01.002

Griffiths, M.L., Drysdale, R.N., Vonhof, H.B., Gagan, M.K., Zhao, J.-X., Ayliffe, L.K., Hantoro, W.S., Hellstrom, J.C., Cartwright, I., Frisia, S., Suwargadi, B.W., 2010b. Younger Dryas-Holocene temperature and rainfall history of southern Indonesia from $\delta 180$ in speleothem calcite and fluid inclusions. Earth Planet. Sci. Lett. 295, 30-36, doi:10.1016/j.epsl.2010.03.018.

Grootes, P.M., Stuiver, M., 1997. Oxygen 18/16 variability in Greenland snow and ice with $10^{-3}$ - to $10^{5}$-year time resolution. J. Geophys. Res. 102, 26,455-426,470.

Hansen, J., Sato, M., Ruedy, R., Kharecha, P., Lacis, A., Miller, R., Nazarenko, L., Lo, K., Schmidt, G.A., Russell, G., Aleinov, I., Bauer, S., Baum, E., Cairns, B., Canuto, V., Chandler, M., Cheng, Y., Cohen, A., Del Genio, A., Faluvegi, G., Fleming, E., Friend, A. Hall, T., Jackman, C., Jonas, J., et al., 2007. Climate simulations for 1880-2003 with GISS modelE. Clim. Dynam. 29, 661-696, doi:10.1007/s00382-007-0255-8.

Heinrich, H., 1988. Origin and consequence of cyclic ice rafting in the northeast Atlantic Ocean during the past 130, 000 years. Quat. Res. 29, 142-152, doi:10.1016/00335894(88)90057-9.

Hellstrom, J., 2006. U-Th dating of speleothems with high initial ${ }^{230} \mathrm{Th}$ using stratigraphical constraint. Quat. Geochronol. 1, 289-295, doi:10.1016/j.quageo.2007.01.004.

Hemming, S.R., 2004. Heinrich events: massive late Pleistocene detritus layers of the North Atlantic and their global climate imprint. Rev. Geophys. 42, doi:10.1029/ 2003RG000128.

Hendy, C.H., 1971. The isotopic geochemistry of speleothems -I. The calculation of the effects of different modes of formation on the isotopic composition of speleothems and their applicability as palaeoclimatic indicators. Geochim. Cosmochim. Acta 35, 801-824.

Johnson, K.R., Hu, C., Belshaw, N.S., Henderson, G.M., 2006. Seasonal trace-element and stable-isotope variations in a Chinese speleothem: the potential for high-resolution paleomonsoon reconstruction. Earth Planet. Sci. Lett. 244, 394-407, doi:10.1016/j. epsl.2006.01.064.

Kageyama, M., Paul, A., Roche, D.M., Van Meerbeeck, C.J., 2010. Modelling glacial climatic millennial-scale variability related to changes in the Atlantic meridiona overturning circulation: a review. Quatern. Sci. Rev. 29, 2931-2956, doi:10.1016/j. quascirev.2010.05.029.

Kelley, M., 2003. Water Tracers and the Hydrologic Cycle in a GCM. Department of Earth and Environmental Sciences, Columbia University, Doctor of Philosophy.

LeGrande, A.N., Schmidt, G.A., 2009. Sources of Holocene variability of oxygen isotopes in paleoclimate archives. Clim. Past 5, 441-455, doi:10.5194/cp-5-441-2009.

Lewis, S.C., LeGrande, A.N., Kelley, M., Schmidt, G.A., 2010. Water vapour source impacts on oxygen isotope variability in tropical precipitation during Heinrich events. Clim. Past 6, 325-343, doi:10.5194/cp-6-325-2010.

McCulloch, M.T., Mortimer, G.E., 2008. Applications of the ${ }^{238} \mathrm{U}-{ }^{230} \mathrm{Th}$ decay series to dating of fossil and modern corals using MC-ICPMS. Aust. J. Earth Sci. 55, 955-965 doi:10.1080/08120090802097435.

Muller, J., Kylander, M., Wust, R.A.J., Weiss, D., Martinez-Cortizas, A., LeGrande, A.N., Jennerjahn, T., Behling, H., Anderson, W.T., Jacobson, G., 2008. Possible evidence for wet Heinrich phases in tropical NE Australia: the Lynch's Crater deposit. Quatern. Sci. Rev. 27, 468-475, doi:10.1016/j.quascirev.2007.11.006.

Partin, J.W., Cobb, K.M., Adkins, J.F., Clark, B., Fernandez, D.P., 2007. Millennial-scale trends in west Pacific warm pool hydrology since the Last Glacial Maximum. Nature 449, 452-455, doi:10.1038/nature06164.

Rozanski, K., Araguas-Araguas, L., Gonfiantini, R., 1993. Isotopic patterns in modern global precipitation. In: Swart, P.K., Lohmann, K.C., McKenzie, J., Savin, S. (Eds.),
Climate change in continental isotopic records. American Geophysical Union, Washington, DC, pp. 1-36.

Schmidt, G.A., Ruedy, R., Hansen, J.E., Aleinov, I., Bell, N., Bauer, M., Bauer, S., Cairns, B. Canuto, V., Cheng, Y., Del Genio, A., Faluvegi, G., Friend, A.D., Hall, T.M., Hu, Y.Y., Kelley, M., Kiang, N.Y., Koch, D., Lacis, A.A., Lerner, J., Lo, K.K., Miller, R.L., Nazarenko, L., Oinas, V., Perlwitz, J., Perlwitz, J., Rind, D., Romanou, A., Russell, G.L., Sato, M., Shindell, D.T., Stone, P.H., Sun, S., Tausnev, N., Thresher, D., Yao, M.S., 2006. Presentday atmospheric simulations using GISS ModelE: comparison to in situ, satellite, and reanalysis data. J. Climate 19, 153-192, doi:10.1175/JCLI3612.1171.

Schmidt, G.A., LeGrande, A.N., Hoffmann, G., 2007. Water isotope expressions of intrinsic and forced variability in a coupled ocean-atmosphere model. J. Geophys. Res. Atmos. 112, doi:10.1029/2006JD007781.

Sinclair, D.J., Kinsley, L.P.J., McCulloch, M.T., 1998. High resolution analysis of trace elements in corals by laser ablation ICP-MS. Geochim. Cosmochim. Acta 62 1889-1901, doi:10.1016/S0016-7037(98)00112-4.

Singarayer, J.S., Valdes, P.J., 2010. High-latitude climate sensitivity to ice-sheet forcing over the last 120 kyr. Quatern. Sci. Rev. 29, 43-55, doi:10.1016/j.quascirev.2009.10.011.

Stouffer, R.J., Yin, J., Gregory, J.M., Dixon, K.W., Spelman, M.J., Hurlin, W., Weaver, A.J., Eby, M., Flato, G.M., Hasumi, H., Hu, A., Jungclaus, J.H., Kamenkovich, I.V., Levermann, A., Montoya, M., Murakami, S., Nawrath, S., Oka, A., Peltier, W.R. Robitaille, D.Y., Sokolov, A., Vettoretti, G., Weber, S.L., 2006. Investigating the causes of the response of the thermohaline circulation to past and future climate changes. J. Climate 19, 1365-1387, doi:10.1175/JCLI3689.1.

Tierney, J.E., Russell, J.M., Huang, Y., Damste, J.S.S., Hopmans, E.C., Cohen, A.S., 2008 Northern Hemisphere controls on tropical southeast African climate during the past 60, 000 years. Science 322, 252-255, doi:10.1126/science.1160485.

Tindall, J.C., Valdes, P.J., Sime, L.C., 2009. Stable water isotopes in HadCM3: isotopic signature of El Niño-Southern Oscillation and the tropical amount effect. J. Geophys. Res. 114, doi:10.1029/2008jd010825.

Treble, P., Shelley, J.M.G., Chappell, J., 2003. Comparison of high resolution sub-annual records of trace elements in a modern (1911-1992) speleothem with instrumental climate data from southwest Australia. Earth Planet. Sci. Lett. 216, 141-153, doi:10.1016/S0012-821X(03)00504-1.

Treble, P.C., Schmitt, A.K., Edwards, R.L., McKeegan, K.D., Harrison, T.M., Grove, M., Cheng, H., Wang, Y.J., 2007. High resolution Secondary Ionisation Mass Spectrometry (SIMS) $\delta 180$ analyses of Hulu Cave speleothem at the time of Heinrich Event 1. Chem. Geol. 238, 197-212, doi:10.1016/j.chemgeo.2006.11.009.

Vuille, M., Werner, M., 2005. Stable isotopes in precipitation recording South American summer monsoon and ENSO variability: observations and model results. Clim. Dyn. 25, 401-413, doi:10.1007/s00382-005-0049-9.

Wang, Y.J., Cheng, H., Edwards, R.L., An, Z.S., Wu, J.Y., Shen, C.-C., Dorale, J.A., 2001. A high-resolution absolute-dated late Pleistocene monsoon record from Hulu Cave, China. Science 294, 2345-2348, doi:10.1126/science.1064618.

Wang, X., Auler, A.S., Edwards, R.L., Cheng, H., Cristalli, P.S., Smart, P.L., Richards, D.A., Shen, C.-C., 2004. Wet periods in northeastern Brazil over the past 210-kyr linked to distant climate anomalies. Nature 432, 740-743, doi:10.1038/nature03067.

Wang, X., Auler, A.S., Edwards, R.L., Cheng, H., Ito, E., Solheid, M., 2006. Interhemispheric anti-phasing of rainfall during the last glacial period. Quatern. Sci. Rev. 25, 3391-3403, doi:10.1016/j.quascirev.2006.02.009.

Wang, Y., Cheng, H., Edwards, R.L., Kong, X., Shao, X., Chen, S., Wu, J., Jiang, X., Wang, X. An, Z., 2008. Millennial- and orbital-scale changes in the East Asian monsoon over the past 224, 000 years. Nature 451, 1090-1093, doi:10.1038/nature06692.

Webster, P.J., Yang, S., 1992. Monsoon and ENSO: selectively interactive systems. Q. J. Roy. Metero. Soc. 118, 877-926, doi:10.1002/qj.49711850705.

Wunsch, C., 2006. Abrupt climate change: an alternative view. Quatern. Res. 65, 191-203, doi:10.1016/j.yqres.2005.10.006.

Xie, P., Arkin, P.A., 1996. Analyses of global monthly precipitation using gauge observations, satellite estimates, and numerical model predictions. J. Climate 9, 840-858, doi:10.1175/1520-0442(1996)009.

Zhao, K., Wang, Y., Edwards, R.L., Cheng, H., Liu, D., 2010. High-resolution stalagmite $\delta 180$ records of Asian monsoon changes in central and southern China spanning the MIS 3/2 transition. Earth Planet. Sci. Lett. 298, 191-198.

Zhao,, J.-X., Hu, K., Collerson, K.D., Xu, H.-k., 2001. Thermal ionization mass spectrometry U-series dating of a hominid site near Nanjing. China Geol. 29, 27-30, doi:10.1130/0091-7613(2001)029. 


\section{LR07-E1}

Distance

$\begin{array}{cc}61.17 & \text { Age }(\mathrm{ka}) \\ 70.58 & 25.616 \\ 79.99 & 25.651 \\ 89.75 & 25.678 \\ 99.51 & 25.700 \\ 109.27 & 25.722 \\ 119.03 & 25.744 \\ 128.79 & 25.763 \\ 138.55 & 25.782 \\ 148.31 & 25.801 \\ 158.07 & 25.820 \\ 167.83 & 25.840 \\ 177.59 & 25.862 \\ 187.35 & 25.887 \\ 193.70 & 25.921 \\ 200.05 & 25.959 \\ 209.91 & 26.038 \\ 219.77 & 26.170 \\ 229.63 & 26.189 \\ 239.49 & 26.194 \\ 249.35 & 26.197 \\ 259.21 & 26.199 \\ 269.07 & 26.202 \\ 279.49 & 26.205 \\ 289.91 & 26.207 \\ 300.33 & 26.209 \\ 310.75 & 26.212 \\ 321.17 & 26.216 \\ 331.59 & 26.220 \\ 342.01 & 26.224 \\ 352.43 & 26.228 \\ & 26.234\end{array}$

\section{LR07-E1-D}

Distance $(\mathrm{mm})$

962.60

962.61

962.74

962.88

963.01

963.14

963.27

963.40

963.53

963.67

963.80

963.93

964.06

964.19

964.32

964.46

964.59

964.72

964.85

964.98

965.11

965.24

965.38

965.51

965.64

965.77

965.90

966.03

966.17

966.30

966.43
Age (ka) 30.1438

30.1439

30.1446

30.1454

30.1462

30.1469

30.1477

30.1484

30.1492

30.1500

30.1508

30.1516

30.1523

30.1530

30.1538

30.1547

30.1554

30.1562

30.1570

30.1577

30.1585

30.1592

30.1600

30.1608

30.1615

30.1623

30.1631

30.1639

30.1647

30.1654

30.1662

\section{LR06-C3}

$\delta 180$ (VPDB, \%) $\quad$ Distance (mm) Age (ka) $\delta 180$ (VPDB, \%) $-3.44 \quad 169.1$

178.4

187.8

197.1

206.5

215.9

225.2

234.6

243.9

253.3

262.7

272

281.4

26.132

$-4.19$

26.286

26.439

26.594

26.748

26.901

27.056

27.209

27.363

27.518

27.671

27.825

$-4.03$

$-4.15$

$-4.25$

$-4.49$

$-4.52$

$-4.36$

$-4.33$

$-4.33$

$-4.34$

$-4.45$

$-4.22$

$-4.06$ 


$\begin{array}{llllll}362.85 & 26.239 & -4.51 & 966.56 & 30.1670 & -3.49 \\ 368.06 & 26.242 & -4.45 & 966.69 & 30.1677 & -3.52 \\ 373.27 & 26.245 & -4.03 & 966.82 & 30.1685 & -3.51 \\ 383.29 & 26.256 & -4.18 & 966.96 & 30.1693 & -3.46 \\ 393.31 & 26.271 & -4.21 & 967.09 & 30.1700 & -3.46 \\ 403.33 & 26.285 & -4.10 & 967.22 & 30.1708 & -3.47 \\ 413.35 & 26.298 & -4.30 & 967.35 & 30.1715 & -3.48 \\ 423.37 & 26.311 & -4.41 & 967.48 & 30.1723 & -3.56 \\ 433.39 & 26.321 & -4.46 & 967.58 & 30.1729 & -3.58 \\ 443.41 & 26.331 & -4.36 & 967.60 & 30.1730 & -3.62 \\ 453.43 & 26.341 & -4.57 & 967.70 & 30.1734 & -3.69 \\ 463.45 & 26.350 & -4.46 & 967.90 & 30.1743 & -3.67 \\ 473.47 & 26.359 & -4.54 & 968.20 & 30.1755 & -3.72 \\ 483.49 & 26.368 & -4.52 & 968.30 & 30.1759 & -3.77 \\ 493.51 & 26.378 & -4.54 & 968.40 & 30.1764 & -3.71 \\ 513.55 & 26.398 & -4.68 & 968.50 & 30.1768 & -3.73 \\ 522.53 & 26.407 & -4.60 & 968.70 & 30.1776 & -3.71 \\ 531.51 & 26.416 & -4.63 & 968.90 & 30.1785 & -3.71 \\ 547.37 & 26.436 & -4.29 & 969.10 & 30.1793 & -3.60 \\ 556.82 & 26.451 & -4.45 & 969.30 & 30.1801 & -3.70 \\ 566.27 & 26.466 & -4.43 & 969.50 & 30.1810 & -3.63 \\ 575.72 & 26.471 & -4.60 & 969.70 & 30.1818 & -3.81 \\ 585.17 & 26.475 & -4.48 & 969.90 & 30.1826 & -3.84 \\ 594.62 & 26.488 & -4.37 & 970.10 & 30.1835 & -3.92 \\ 604.07 & 26.551 & -4.43 & 970.30 & 30.1843 & -3.88 \\ 613.52 & 26.583 & -4.64 & 970.40 & 30.1847 & -3.89 \\ 622.97 & 26.606 & -4.58 & 970.50 & 30.1851 & -3.93 \\ 632.42 & 26.624 & -4.45 & 970.60 & 30.1855 & -3.81 \\ 641.87 & 26.641 & -4.69 & 970.70 & 30.1859 & -3.80 \\ 651.32 & 26.657 & -4.59 & 970.90 & 30.1868 & -3.73 \\ 660.77 & 26.672 & -4.56 & 971.10 & 30.1876 & -3.71 \\ 670.22 & 26.687 & -4.42 & 971.30 & 30.1884 & -3.55 \\ 674.95 & 26.694 & -4.41 & 971.50 & 30.1893 & -3.43 \\ 679.68 & 26.701 & -4.24 & 971.70 & 30.1901 & -3.41\end{array}$




\begin{tabular}{|c|c|c|c|c|c|}
\hline 690.04 & 26.717 & -4.43 & 971.90 & 30.1910 & -3.46 \\
\hline 700.40 & 26.733 & -4.58 & 972.10 & 30.1918 & -3.50 \\
\hline 710.76 & 26.751 & -4.28 & 972.30 & 30.1926 & -3.53 \\
\hline 721.12 & 26.767 & -4.11 & 972.50 & 30.1935 & -3.57 \\
\hline 731.48 & 26.784 & -4.38 & 972.70 & 30.1943 & -3.50 \\
\hline 741.84 & 26.802 & -4.57 & 972.90 & 30.1951 & -3.46 \\
\hline 752.20 & 26.820 & -4.63 & 973.10 & 30.1959 & -3.46 \\
\hline 762.56 & 26.841 & -4.17 & 973.30 & 30.1966 & -3.47 \\
\hline 772.92 & 26.866 & -4.34 & 973.50 & 30.1974 & -3.42 \\
\hline 783.28 & 26.903 & -4.38 & 973.70 & 30.1981 & -3.38 \\
\hline 788.46 & 26.956 & -4.13 & 973.90 & 30.1988 & -3.35 \\
\hline 793.64 & 27.004 & -3.74 & 974.10 & 30.1995 & -3.30 \\
\hline 803.37 & 27.079 & -4.39 & 974.30 & 30.2002 & -3.32 \\
\hline 813.10 & 27.149 & -4.06 & 974.50 & 30.2009 & -3.37 \\
\hline 822.83 & 27.214 & -4.09 & 974.70 & 30.2016 & -3.40 \\
\hline 832.56 & 27.280 & -4.24 & 974.90 & 30.2022 & -3.44 \\
\hline 842.29 & 27.347 & -3.70 & 975.10 & 30.2030 & -3.40 \\
\hline 852.02 & 27.421 & -4.27 & 975.30 & 30.2036 & -3.42 \\
\hline 861.75 & 27.506 & -4.66 & 975.50 & 30.2043 & -3.35 \\
\hline 871.48 & 27.613 & -4.40 & 975.70 & 30.2050 & -3.33 \\
\hline 881.21 & 27.656 & -4.18 & 976.10 & 30.2064 & -3.28 \\
\hline 890.94 & 27.681 & -4.31 & 976.30 & 30.2071 & -3.32 \\
\hline 900.67 & 27.703 & -4.40 & 976.50 & 30.2078 & -3.32 \\
\hline 910.40 & 27.724 & -4.09 & 976.70 & 30.2085 & -3.34 \\
\hline 920.13 & 27.745 & -3.65 & 976.90 & 30.2092 & -3.33 \\
\hline 929.86 & 27.769 & -4.03 & 977.10 & 30.2099 & -3.36 \\
\hline 939.59 & 27.799 & -4.43 & 977.30 & 30.2106 & -3.44 \\
\hline hiatus & & & 977.50 & 30.2112 & -3.53 \\
\hline 959.97 & 30.140 & -3.49 & 977.70 & 30.2120 & -3.60 \\
\hline 970.02 & 30.183 & -3.74 & 977.90 & 30.2127 & -3.61 \\
\hline 980.07 & 30.220 & -4.10 & 978.00 & 30.2130 & -3.54 \\
\hline 990.12 & 30.251 & -3.94 & 978.10 & 30.2133 & -3.66 \\
\hline 1000.17 & 30.280 & -3.55 & 978.30 & 30.2141 & -3.61 \\
\hline 1010.22 & 30.308 & -3.49 & 978.50 & 30.2147 & -3.63 \\
\hline
\end{tabular}




$\begin{array}{llllll}1020.27 & 30.334 & -3.94 & 978.60 & 30.2151 & -3.62 \\ 1030.32 & 30.359 & -4.08 & 978.70 & 30.2154 & -3.68 \\ 1040.37 & 30.384 & -3.73 & 978.80 & 30.2158 & -3.58 \\ 1050.42 & 30.411 & -3.63 & 978.90 & 30.2161 & -3.59 \\ 1055.45 & 30.424 & -4.08 & 979.10 & 30.2167 & -3.58 \\ 1060.47 & 30.438 & -4.29 & 979.30 & 30.2174 & -3.60 \\ 1070.64 & 30.463 & -3.88 & 979.50 & 30.2181 & -3.50 \\ 1080.81 & 30.488 & -4.13 & 979.60 & 30.2184 & -3.46 \\ 1090.98 & 30.515 & -3.72 & 979.70 & 30.2187 & -3.44 \\ 1101.15 & 30.542 & -3.81 & 979.80 & 30.2191 & -3.45 \\ 1111.32 & 30.571 & -3.80 & 979.90 & 30.2194 & -3.50 \\ 1121.49 & 30.602 & -3.63 & 980.10 & 30.2201 & -3.50 \\ 1131.66 & 30.633 & -3.79 & 980.30 & 30.2207 & -3.44 \\ 1141.83 & 30.669 & -4.11 & 980.50 & 30.2214 & -3.54 \\ 1152.00 & 30.709 & -4.44 & 980.70 & 30.2220 & -3.52 \\ 1162.17 & 30.758 & -3.85 & 980.90 & 30.2227 & -3.56 \\ 1172.34 & 30.810 & -3.94 & 981.10 & 30.2234 & -3.56 \\ 1182.51 & 30.853 & -4.18 & 981.30 & 30.2241 & -3.62 \\ 1192.68 & 30.888 & -4.20 & 981.50 & 30.2248 & -3.63 \\ 1202.85 & 30.920 & -4.04 & 981.70 & 30.2254 & -3.67 \\ 1213.02 & 30.951 & -4.30 & 981.90 & 30.2261 & -3.70 \\ 1223.19 & 30.980 & -4.16 & 982.10 & 30.2268 & -3.78 \\ 1233.36 & 31.009 & -4.23 & 982.30 & 30.2274 & -3.74 \\ 1243.53 & 31.038 & -4.32 & 982.50 & 30.2281 & -3.77 \\ 1253.70 & 31.069 & -4.30 & 982.70 & 30.2287 & -3.87 \\ 1263.87 & 31.106 & -4.33 & 982.90 & 30.2294 & -3.84 \\ 1273.68 & 31.150 & -4.17 & 983.00 & 30.2298 & -3.92 \\ 1283.49 & 31.156 & -3.94 & 983.10 & 30.2301 & -4.04 \\ 1293.30 & 31.159 & -4.14 & 983.20 & 30.2304 & -3.95 \\ 1303.11 & 31.161 & -4.39 & 983.30 & 30.2308 & -3.92 \\ 1312.92 & 31.162 & -4.42 & 983.50 & 30.2315 & -3.92 \\ 1322.73 & 31.164 & -4.27 & 983.70 & 30.2321 & -3.97 \\ 1332.54 & 31.166 & -4.16 & 983.90 & 30.2327 & -3.89 \\ 1342.35 & 31.168 & -4.09 & 984.10 & 30.2334 & -4.04\end{array}$




$\begin{array}{llllll}1352.16 & 31.169 & -4.27 & 984.30 & 30.2340 & -3.98 \\ 1361.97 & 31.173 & -4.23 & 984.50 & 30.2346 & -4.19 \\ 1371.78 & 31.175 & -4.46 & 984.70 & 30.2352 & -4.41 \\ 1381.59 & 31.178 & -4.42 & 984.90 & 30.2358 & -4.42 \\ 1391.40 & 31.180 & -4.49 & 985.10 & 30.2364 & -4.37 \\ 1401.21 & 31.189 & -4.16 & 985.30 & 30.2369 & -4.43 \\ 1411.02 & 31.236 & -4.39 & 985.50 & 30.2375 & -4.49 \\ 1420.83 & 31.276 & -4.16 & 985.60 & 30.2378 & -4.57 \\ 1425.74 & 31.294 & -4.03 & 985.70 & 30.2381 & -4.59 \\ 1430.64 & 31.311 & -4.22 & 985.80 & 30.2384 & -4.45 \\ 1440.73 & 31.346 & -4.43 & 985.90 & 30.2386 & -4.30 \\ 1450.82 & 31.388 & -4.36 & 986.00 & 30.2389 & -4.16 \\ 1460.91 & 31.433 & -4.11 & 986.10 & 30.2392 & -4.18 \\ 1471.00 & 31.443 & -3.79 & 986.30 & 30.2398 & -4.10 \\ 1481.09 & 31.445 & -4.13 & 986.50 & 30.2403 & -3.92 \\ 1491.18 & 31.446 & -4.22 & 986.70 & 30.2409 & -3.78 \\ 1501.27 & 31.447 & -3.98 & 986.90 & 30.2414 & -3.72 \\ 1511.36 & 31.449 & -3.97 & 987.10 & 30.2420 & -3.95 \\ 1521.45 & 31.450 & -4.13 & 987.30 & 30.2426 & -4.08 \\ 1531.54 & 31.453 & -4.37 & 987.50 & 30.2431 & -4.17 \\ 1541.63 & 31.454 & -4.24 & 987.70 & 30.2437 & -4.15 \\ 1551.72 & 31.457 & -4.57 & 987.90 & 30.2442 & -4.05 \\ 1561.81 & 31.459 & -4.43 & 988.10 & 30.2448 & -3.96 \\ 1571.90 & 31.461 & -3.91 & 988.30 & 30.2454 & -4.00 \\ 1581.99 & 31.463 & -3.77 & 988.50 & 30.2459 & -4.02 \\ 1592.08 & 31.464 & -4.11 & 988.70 & 30.2465 & -4.11 \\ 1602.17 & 31.466 & -4.04 & 988.90 & 30.2470 & -4.12 \\ 1612.26 & 31.468 & -4.17 & 989.00 & 30.2473 & -4.07 \\ 1622.35 & 31.469 & -4.31 & 989.10 & 30.2476 & -4.28 \\ 1632.44 & 31.470 & -4.21 & 989.30 & 30.2482 & -4.19 \\ 1642.53 & 31.472 & -3.98 & 989.50 & 30.2487 & -4.24 \\ 1652.62 & 31.474 & -3.86 & 989.60 & 30.2490 & -4.26 \\ 1662.71 & 31.475 & -3.99 & 989.70 & 30.2493 & -4.34 \\ 1672.80 & 31.476 & -4.02 & 989.90 & 30.2499 & -4.31\end{array}$




\begin{tabular}{|c|c|c|c|c|c|}
\hline 1682.89 & 31.479 & -3.78 & 990.10 & 30.2505 & -4.16 \\
\hline 1692.98 & 31.481 & -3.96 & 990.30 & 30.2511 & -4.17 \\
\hline 1703.07 & 31.483 & -4.04 & 990.50 & 30.2517 & -4.18 \\
\hline 1713.16 & 31.486 & -4.21 & 990.70 & 30.2523 & -4.18 \\
\hline 1723.25 & 31.489 & -3.99 & 990.90 & 30.2529 & -4.20 \\
\hline 1728.30 & 31.494 & -3.90 & 991.10 & 30.2535 & -4.09 \\
\hline 1733.60 & 31.505 & -4.02 & 991.30 & 30.2541 & -4.07 \\
\hline & & & 991.50 & 30.2547 & -4.08 \\
\hline & & & 991.70 & 30.2553 & -3.99 \\
\hline & & & 991.90 & 30.2559 & -3.87 \\
\hline & & & 992.10 & 30.2565 & -3.87 \\
\hline & & & 992.30 & 30.2571 & -3.93 \\
\hline & & & 992.50 & 30.2577 & -4.05 \\
\hline & & & 992.70 & 30.2583 & -4.24 \\
\hline & & & 992.90 & 30.2589 & -4.32 \\
\hline & & & 993.10 & 30.2595 & -4.23 \\
\hline & & & 993.30 & 30.2600 & -4.23 \\
\hline & & & 993.50 & 30.2606 & -4.33 \\
\hline & & & 993.60 & 30.2609 & -4.38 \\
\hline & & & 993.70 & 30.2612 & -4.46 \\
\hline & & & 993.90 & 30.2618 & -4.57 \\
\hline & & & 994.10 & 30.2624 & -4.16 \\
\hline & & & 994.30 & 30.2630 & -3.87 \\
\hline & & & 994.50 & 30.2636 & -4.00 \\
\hline & & & 994.70 & 30.2642 & -4.13 \\
\hline & & & 994.90 & 30.2648 & -4.23 \\
\hline & & & 995.10 & 30.2654 & -4.17 \\
\hline & & & 995.30 & 30.2660 & -4.03 \\
\hline & & & 995.50 & 30.2666 & -3.84 \\
\hline & & & 995.70 & 30.2672 & -3.83 \\
\hline & & & 995.90 & 30.2678 & -3.91 \\
\hline & & & 996.10 & 30.2683 & -3.97 \\
\hline & & & 996.30 & 30.2689 & -4.02 \\
\hline & & & 996.50 & 30.2695 & -4.22 \\
\hline
\end{tabular}




$\begin{array}{lll}996.70 & 30.2701 & -4.30 \\ 996.80 & 30.2704 & -4.36 \\ 996.90 & 30.2707 & -4.21 \\ 997.00 & 30.2710 & -4.41 \\ 997.10 & 30.2713 & -3.94 \\ 997.20 & 30.2715 & -3.81 \\ 997.30 & 30.2718 & -3.76 \\ 997.50 & 30.2724 & -3.79 \\ 997.70 & 30.2757 & -4.02 \\ 997.90 & 30.2817 & -4.23\end{array}$

